\title{
Mechanistic Insights into the Chaperoning of Human Lysosomal-Galactosidase Activity: Highly Functionalized Aminocyclopentanes and C-5a-Substituted Derivatives of 4-epi-Isofagomine
}

\author{
Patrick Weber ${ }^{1, \dagger}$, Martin Thonhofer ${ }^{1, \dagger}$, Summer Averill ${ }^{1}$, Gideon J. Davies ${ }^{2}{ }^{\mathbb{D}}$, \\ Andres Gonzalez Santana ${ }^{3}$, Philipp Müller ${ }^{4}$, Seyed A. Nasseri ${ }^{3}$, Wendy A. Offen ${ }^{2}{ }^{\circ}$, \\ Bettina M. Pabst ${ }^{5}$, Eduard Paschke ${ }^{5}$, Michael Schalli ${ }^{1}$, Ana Torvisco ${ }^{4}$ (D), \\ Marion Tschernutter ${ }^{5}(\mathbb{D})$, Christina Tysoe ${ }^{3}$, Werner Windischhofer ${ }^{5}$, Stephen G. Withers ${ }^{3}(\mathbb{D}$, \\ Andreas Wolfsgruber ${ }^{1}$, Tanja M. Wrodnigg ${ }^{1}$ and Arnold E. Stütz ${ }^{1, *}$ \\ 1 Glycogroup, Institute of Chemistry and Technology of Biobased Systems, Graz University of Technology, \\ Stremayrgasse 9, A-8010 Graz, Austria; patrick.weber@tugraz.at (P.W.); thonhofer@tugraz.at (M.T.); \\ seaveril@uvm.edu (S.A.); michael.schalli@medunigraz.at (M.S.); andreas.wolfsgruber@tugraz.at (A.W.); \\ t.wrodnigg@tugraz.at (T.M.W.) \\ 2 Department of Chemistry, University of York, Heslington, York YO10 5DD, North Yorkshire, UK; \\ gideon.davies@york.ac.uk (G.J.D.); wendy.offen@york.ac.uk (W.A.O.) \\ 3 Chemistry Department, University of British Columbia, 2036 Main Mall, Vancouver, BC V6T 1Z1, Canada; \\ aglez@chem.ubc.ca (A.G.S.); snasseri@chem.ubc.ca (S.A.N.); christina.tysoe@gmail.com (C.T.); \\ withers@chem.ubc.ca (S.G.W.) \\ 4 Institute of Inorganic Chemistry, Graz University of Technology, Stremayrgasse 9, A-8010 Graz, Austria; \\ philipp.mueller@tugraz.at (P.M.); ana.torviscogomez@tugraz.at (A.T.) \\ 5 Laboratory of Metabolic Diseases, Department of Pediatrics, MedUni Graz, Auenbruggerplatz 30, \\ A-8036 Graz, Austria; bettina.pabst@medunigraz.at (B.M.P.); eduard.paschke@inode.at (E.P.); \\ marion.tschernutter@medunigraz.at (M.T.); werner.windischhofer@medunigraz.at (W.W.) \\ * Correspondence: stuetz@tugraz.at; Tel.: +43-316-873-32079 \\ + These authors contributed equally to this paper.
}

Academic Editor: László Somsák

Received: 29 July 2020; Accepted: 25 August 2020; Published: 3 September 2020

\begin{abstract}
Glycosidase inhibitors have shown great potential as pharmacological chaperones for lysosomal storage diseases. In light of this, a series of new cyclopentanoid $\beta$-galactosidase inhibitors were prepared and their inhibitory and pharmacological chaperoning activities determined and compared with those of lipophilic analogs of the potent $\beta$-D-galactosidase inhibitor 4-epi-isofagomine. Structure-activity relationships were investigated by $\mathrm{X}$-ray crystallography as well as by alterations in the cyclopentane moiety such as deoxygenation and replacement by fluorine of a "strategic" hydroxyl group. New compounds have revealed highly promising activities with a range of $\beta$-galactosidase-compromised human cell lines and may serve as leads towards new pharmacological chaperones for $\mathrm{G}_{\mathrm{M} 1}$-gangliosidosis and Morquio B disease.
\end{abstract}

Keywords: iminoalditol; 4-epi-isofagomine; carbasugar; aminocyclopentane; galactosidase inhibitor; pharmacological chaperone; $\mathrm{G}_{\mathrm{M} 1}$-gangliosidosis

\section{Introduction}

Many glycoside hydrolases play important roles in various pathological processes, including certain hereditary lysosomal disorders [1-3]. A group of about fifty of these metabolic diseases arises from mutations in specific genes that lead to deficiencies in enzymes involved in 
the lysosomal degradation of glycolipids and glycans. Considerable efforts have been made to develop novel therapeutics that may relieve the symptoms arising from the cellular accumulation of the substrates of these deficient enzymes. These toxic accumulations, in turn, lead to irreversible damage of nerve tissue and bones as well as various organs. For some of these lysosomal disorders, enzyme replacement therapy [4,5], hematopoietic stem cell transplant [6,7], gene therapy [8,9], as well as combination therapies [10] involving the administration of small molecules show considerable promise. These small molecules may function by one of the following two mechanisms: Either by substrate reduction therapy [11-13] —inhibiting upstream enzymes to reduce the initial production of those metabolites whose degradation is impaired or as enzyme-stabilizing pharmacological chaperones by assisting the folding and transport of mutant enzymes to the lysosome using sub-inhibitory concentrations of active site-specific molecules (chaperone mediated therapy, CMT) [14-22].

Efforts of many groups have shown that imino sugar- as well as carba sugar-based glycomimetics may be suitable as such therapeutic agents. Mutant proteins that cannot obtain/retain their functional conformation are recognized as misfolded by the quality control machinery in the endoplasmic reticulum and are eventually targeted for degradation. In CMT, the carba or imino sugars bind to and stabilize mutant forms of enzymes (such as lysosomal $\beta$-glucosidase, $\beta$-galactosidase or $\beta$ - $N$-acetylhexosaminidase) in their functional folded conformations and thus facilitate their exit from the endoplasmic reticulum and their subsequent transport to the lysosome.

Guiding contributions by various leaders in the field and recent reviews [23-26] have shown that non-polar $N$-substituted iminoalditols and similarly functionalized structures bind better than their more polar parent compounds. This is achieved through stronger interactions with the aglycon binding site or with lipophilic pockets around the active site. In this context, $N$-butyl-1-deoxynojirimycin is one of the best studied iminosugars, thus far [27]. Other researchers [28-31] have observed that large, lipophilic substituents, for example, adamantyl capped spacer arms, greatly improve the interaction between iminoalditol derivatives and the lysosomal $\beta$-glucosidase (Figure 1).
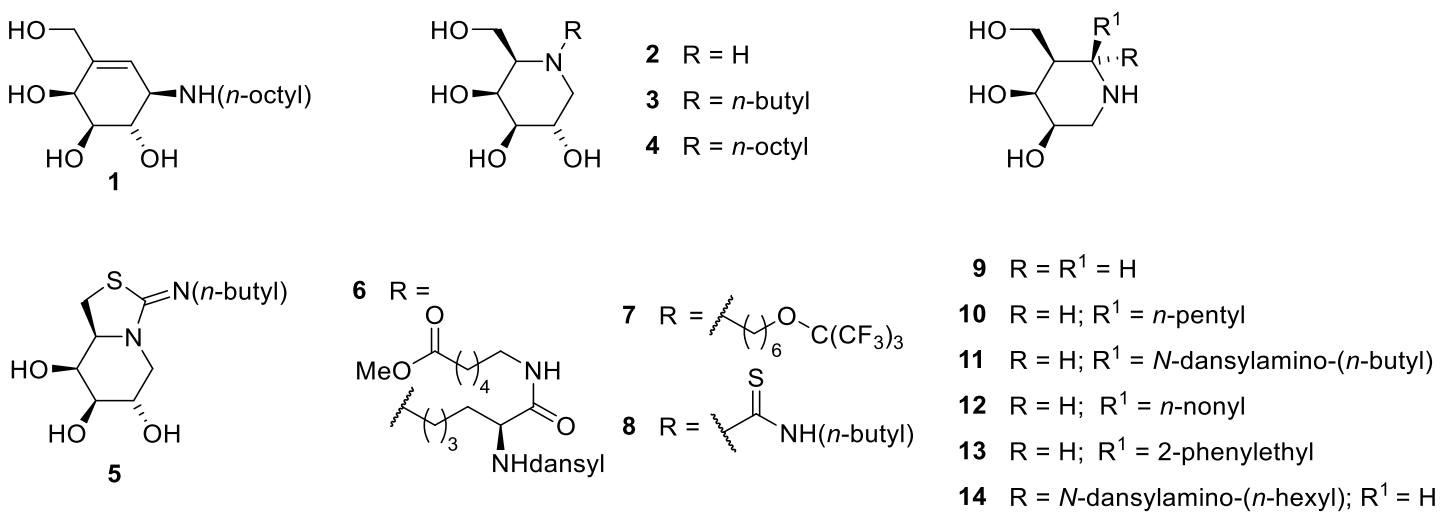

Figure 1. Galactosidase inhibitors as potential therapeutic chaperones for mutation induced deficiencies of lysosomal $\beta$-galactosidase.

$\mathrm{G}_{\mathrm{M} 1}$-Gangliosidosis and Morquio B disease are two manifestations of mutations on the GLB1 gene that encodes the vital lysosomal $\beta$-galactosidase. This enzyme is responsible for removal of a $\beta$-galactosyl residue from the non-reducing end of its substrate, converting gangliosides $G_{M 1}$ and $G_{A 1}$ into $G_{M 2}$ and $G_{A 2}$, respectively. Depending on the location of the mutation, the resulting lysosomal storage disorder is neurodegenerative ( $\mathrm{G}_{\mathrm{M} 1}$-gangliosidosis) or bone-destructive (Morquio $\left.\mathrm{B}\right)[32,33]$.

Three distinct structural types of $\beta$-galactosidase inhibitors have been investigated as potential pharmacological chaperones for these two disorders. The first class is that of the epi-valienamines, of which NOEV ( $N$-octyl-epi-valienamine, 1, Figure 1 ) is a powerful $\beta$-galactosidase inhibitor [34] and reportedly functions as a highly potent pharmacological chaperone for a wide range of mutants of lysosomal $\beta$-galactosidase, even at sub-micromolar concentrations [35]. More recently, 
selected un-branched analogs lacking the hydroxymethyl group have been presented and their activities with patients' skin fibroblasts carrying the R201C mutation have been evaluated [36]. The second class of potential chaperones are the hydroxylated piperidines exemplified by the deoxygalactonojirimycins, 2-4. Through a variety of structural modifications, this scaffold has been transformed into a relatively small number of derivative classes. Compounds 3-8 show several of the most active $N$-substituent-variants in the literature, which have interesting properties as experimental pharmacological chaperones. [22,37-44]. C-5a-substituted derivatives of the known [45] isoiminosugar 4-epi-isofagomine (9), for example, compounds 10-14 have recently been reported and shown to be potent $\beta$-galactosidase inhibitors and superior pharmacological chaperones for selected $\mathrm{G}_{\mathrm{M} 1}$-gangliosidosis and Morquio B disease cell lines [46-50].

The third class are the hydroxymethyl branched di- and trihydroxycyclopentylamines, which were recently introduced as experimental pharmacological chaperones [51]. These compounds may be regarded as products of ring contraction by formal homolytic extraction of the sugar ring oxygen and bond formation between C-1 and C-5. The resulting carbacyclic scaffold maintains the stereochemical information of the corresponding parent sugar or glycosylamine albeit with the characteristic conformational features of five-membered rings. There are only three leading references presenting such sugar analogues as proven D-galactosidase inhibitors [52-54]. Even more surprisingly, this family of compounds reportedly harbours some of the most powerful inhibitors of $\beta$-galactosidases known to date with inhibition constants in the sub-nanomolar range [52-54]. In particular, the $\beta$-D-galacto configured cyclopentylamine bearing a 4-bromobenzyl moiety at the nitrogen (15, Figure 2), has been found to excel in terms of inhibitory activity [52-54] and recently prepared [55] compounds $\mathbf{1 6}$ and $\mathbf{1 7}$ are powerful inhibitors of human lysosomal $\beta$-galactosidase and potent pharmacological chaperones for the R201C mutant of this enzyme.

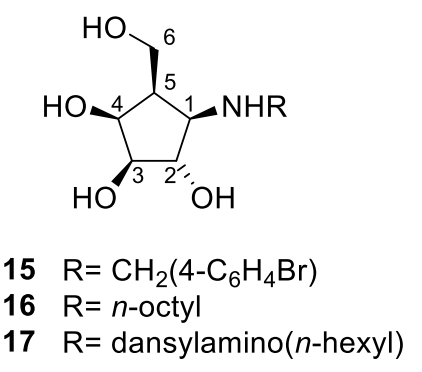

Figure 2. Inhibitors 15-17.

In this study, which aims to extend the selection of chaperone structures useful for treating $\mathrm{G}_{\mathrm{M} 1}$-gangliosidosis and Morquio B, we have investigated the effect of 4-epi-isofagomine derivatives featuring dansylamino capped medium chain length aliphatic substituents. We have furthermore explored the biochemical role of the $\mathrm{OH}$ group at $\mathrm{C}-2$, which is a key functional group in natural $\beta$-galactosidase substrates but is not present in the 4-epi-isofagomine inhibitors. This has consequences both on the specific binding interactions formed and indirectly, on the basicity of the ring nitrogen compared to the $\beta$-hydroxy substituted imino (2-8) or carba sugars such as 15, 16 and 17.

\section{Results}

\subsection{Synthesis of 4-epi-Isofagomines}

By analogy to the synthesis of $(5 a S)$-dansylaminohexyl derivative 14 [46,47], (Figure 1) its (5aR)-epimer 22 was prepared from known intermediate aldehyde 18 [56], by Wittig chain extension employing triphenyl-(3-cyano)propyl phosphonium bromide to obtain nitrile 19. Subsequent terminal modification, via primary amine $\mathbf{2 0}$ and protected 4-epi-isofagomine derivative $\mathbf{2 1}$ provided free compound 22 featuring a dansyl capped aminohexyl chain at $R$-configured C-5a (Scheme 1). 


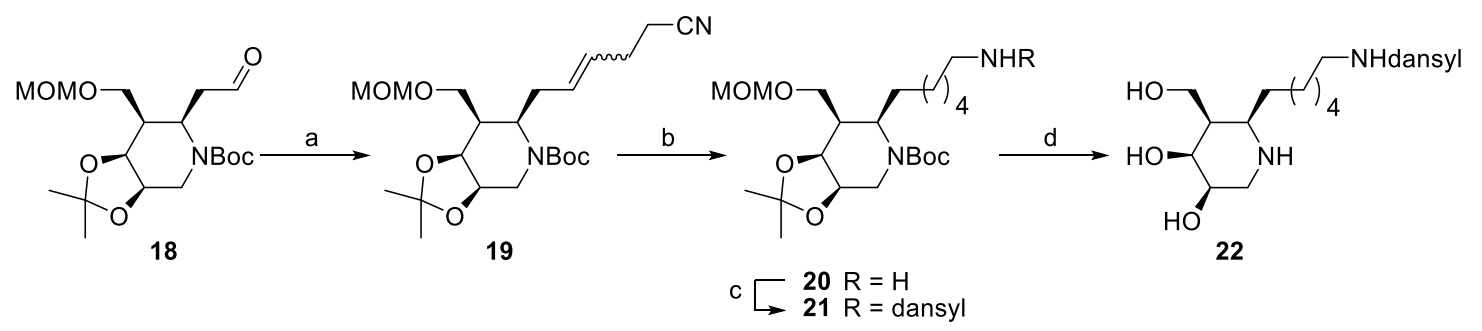

Scheme 1. Synthesis of inhibitor 22. a: $\mathrm{Ph}_{3} \mathrm{P}\left(\mathrm{CH}_{2}\right)_{3} \mathrm{CN} \mathrm{Br}, \mathrm{LDA}, \mathrm{THF}_{(\mathrm{abs})}, \mathrm{N}_{2},-78{ }^{\circ} \mathrm{C}$ to r.t., $66 \%$; b: Raney-Ni, $\mathrm{H}_{2}, \mathrm{MeOH}, 84 \%$; c: dansyl chloride, $\mathrm{NaHCO}_{3}, \mathrm{MeOH}, 61 \%$; d: $\mathrm{HCl} / \mathrm{MeOH}, 74 \%$.

\subsection{Synthesis of Cyclopentylamines}

Dansylaminohexyl substituted cyclopentane $\mathbf{1 7}$ was synthesized as described [55]. The corresponding deoxy derivative $\mathbf{3 1}$ was prepared from the recently reported [57] all-cis epimer 23 (Scheme 2). Activation of the free alcohol as a triflate (24) and treatment of the latter with sodium bromide in DMF gave bromodeoxy derivative $\mathbf{2 5}$ with clean inversion of configuration. Simultaneous removal of the bromo substituent and reductive isoxazolidine ring opening were achieved by use of Raney- $\mathrm{Ni} / \mathrm{H}_{2}$ in $\mathrm{MeOH}$, providing aminoalcohol $\mathbf{2 6}$ which, upon acid treatment, furnished free aminotriol $\mathbf{2 7}$ ready for planned chemoselective $N$-alkylation $[48,49,51]$, but, as a consequence of solubility problems, this reaction was subsequently conducted with partially protected intermediate $\mathbf{2 6}$ (Scheme 2).

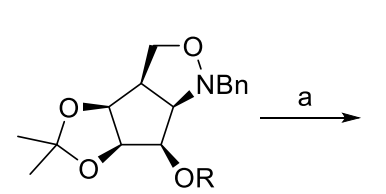

$23 \mathrm{R}=\mathrm{H}$

$24 \mathrm{R}=\mathrm{SO}_{2} \mathrm{CF}_{3}$

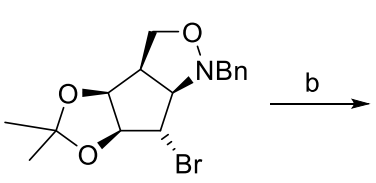

25

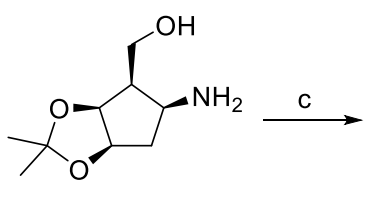

26<smiles>N[C@H]1C[C@@H](O)[C@H](O)[C@H]1CO</smiles>

27

Scheme 2. Synthesis of 2-deoxy intermediate 26. a: (1) $\mathrm{Tf}_{2} \mathrm{O}$, pyridine, $\mathrm{CH}_{2} \mathrm{Cl}_{2}, 0{ }^{\circ} \mathrm{C}$; (2) $\mathrm{NaBr}, \mathrm{DMF}$, $53 \%$ (2 steps); b: Raney-Ni, $\mathrm{H}_{2}, \mathrm{MeOH}, 66 \%$; c: $\mathrm{HCl} / \mathrm{MeOH}, 88 \%$.

Isopropylidene-protected amine $\mathbf{2 6}$ was chemoselectively alkylated to provide nitrile $\mathbf{2 8}$ (Scheme 3) which, in turn, was cleanly converted into primary amine 29 by catalytic hydrogenation over Raney-Ni. Subsequent $N$-dansylation (30) and removal of the isopropylidene moiety gave deprotected deoxy derivative $\mathbf{3 1}$ of parent compound $\mathbf{1 7}$ (Scheme 3).

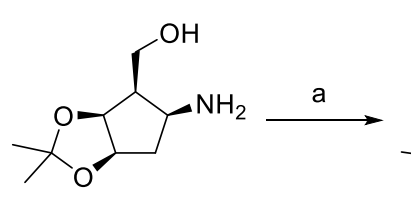

26

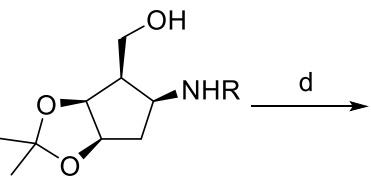

$\begin{array}{ll}\mathrm{b} \longrightarrow & \mathrm{R}=\left(\mathrm{CH}_{2}\right)_{5} \mathrm{CN} \\ \mathrm{C} \underset{29}{ } \mathrm{R}=\left(\mathrm{CH}_{2}\right)_{6} \mathrm{NH}_{2} \\ \longrightarrow 30 \mathrm{R}=\left(\mathrm{CH}_{2}\right)_{6} \mathrm{NH} \text { dansyl }\end{array}$<smiles>NCCCCCCCNC1CC(O)C(O)C1CO</smiles>

31

Scheme 3. Synthesis of compound 31. a: $\mathrm{Br}\left(\mathrm{CH}_{2}\right)_{5} \mathrm{CN}, \mathrm{NaHCO}_{3}, \mathrm{DMF}, 70{ }^{\circ} \mathrm{C}, 62 \%$; b: Raney-Ni, $\mathrm{H}_{2}$, $\mathrm{MeOH}, 78 \%$; c: (1) dansyl chloride, $\mathrm{Et}_{3} \mathrm{~N}, \mathrm{CH}_{2} \mathrm{Cl}_{2}$-DMF (3:1); d: $\mathrm{HCl} / \mathrm{MeOH}, 84 \%$ (2 steps).

In order to evaluate the influence of "polar deoxygenation" at C-2, the novel deoxyfluoro analogue 37 was synthesized by reaction of precursor 23 with DAST to furnish compound 32 and subsequent structural elaboration via intermediates 33-36 by analogous methods to those described for derivative 31 (Scheme 4). 

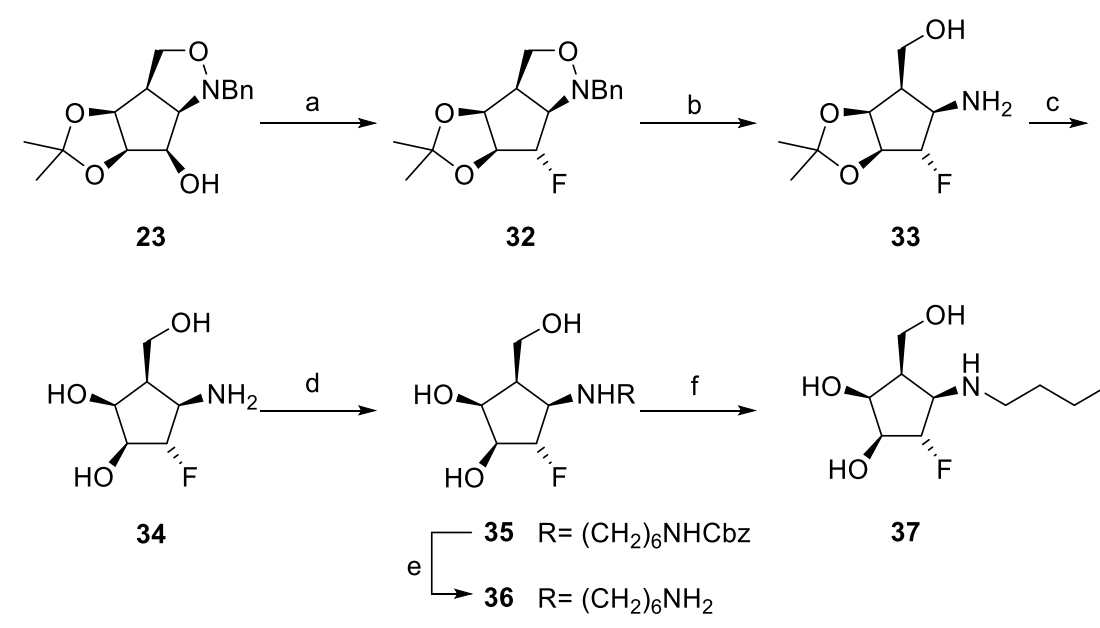<smiles>NCCCCCCN[C@@H]1[C@H](F)[C@@H](O)[C@H](O)[C@@H]1CO</smiles>

37

Scheme 4. Synthesis of 2-deoxy-2-fluoro compound 37. a: DAST, pyridine, $\mathrm{CH}_{2} \mathrm{Cl}_{2},{ }^{\circ} \mathrm{C}, 82 \%$; b: $\mathrm{Pd} / \mathrm{C}$, $\mathrm{H}_{2}, \mathrm{MeOH}, 98 \%$; c: $\mathrm{HCl} / \mathrm{MeOH}, 92 \%$; d: $\mathrm{HCO}\left(\mathrm{CH}_{2}\right)_{6} \mathrm{NHCbz} \mathrm{NaCNBH}_{3}, \mathrm{AcOH}, \mathrm{MeOH}, 60 \%$; e: $\mathrm{Pd} / \mathrm{C}$, $\mathrm{H}_{2}, \mathrm{MeOH}$; f: dansyl chloride, $\mathrm{Et}_{3} \mathrm{~N}, \mathrm{CH}_{3} \mathrm{CN}-\mathrm{H}_{2} \mathrm{O}(5: 1), 53 \%$.

The structure of intermediate 33 was confirmed by X-ray analysis (Figure 3).

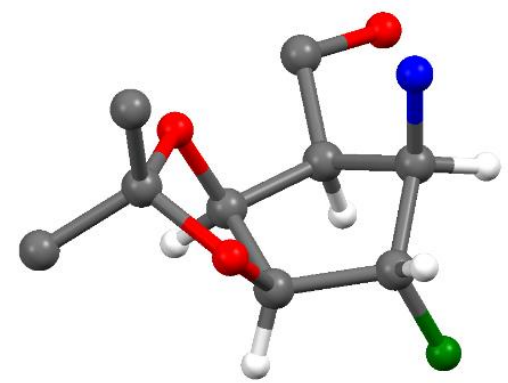

Figure 3. Crystal structure of compound 33 (CCDC 2018297).

\subsection{Inhibitory Activities}

Results of screening of new isofagomine derivative 22 as well as cyclopentanes 31 and 37 in comparison with their previously reported respective relatives 11, 16 and 17 as well as pyranoid carbasugar derivative 1 employing a panel of representative D-galactosidases and D-glucosidases are collected in Table 1. Inhibition constants across the series tend to favor the binding of the piperidine structure 22, with all $\beta$-glycosidases tested being inhibited in the low to sub-nanomolar range. Close behind this in affinity comes the new dansylated cyclopentanoid inhibitor 17. Most of the $\beta$-glycosidases are inhibited in the low, but not sub-, nanomolar range, with the exceptions being the human lysosomal $\beta$-galactosidase (from CAZY [58,59] family GH35) and human lysosomal $\beta$-glucocerebrosidase. 
Table 1. $K_{\mathrm{i}}$-values $[\mu \mathrm{M}]$ of compounds with $\mathrm{Abg}=\beta$-glucosidase/ $\beta$-galactosidase from Agrobacterium sp.; E. coli=lac Z $\beta$-galactosidase from E. coli; Bovine liver $=$ $\beta$-galactosidase from bovine liver; Fabrazyme $=$ commercial recombinant lysosomal $\alpha$-galactosidase; $S$. cer. $=\alpha$-glucosidase from S. cerevisiae; GCase $=$ recombinant human lysosomal $\beta$-glucocerebrosidase; $\beta$-Gal. human lys. = human lysosomal acid $\beta$-galactosidase; $\mathrm{IC}_{50}[\mu \mathrm{M}]$ with $\beta$-Gal (human lysosomal); .i. = no inhibition, with $K_{\mathrm{i}}>1 \mathrm{mM}$.

\begin{tabular}{|c|c|c|c|c|c|c|c|}
\hline \multirow[b]{2}{*}{$\begin{array}{c}\text { Enzyme } \\
\text { (GH Family) }\end{array}$} & \multicolumn{7}{|c|}{ Compounds } \\
\hline & 22 & $>_{14}$ & $\begin{array}{l}\mathrm{OH} \\
16\end{array}$ & $\begin{array}{l}\int^{\mathrm{NH}\left(\mathrm{CH}_{2}\right.} \\
\mathbf{1 7}[55]\end{array}$ & 31 & 37 & $\begin{array}{c}\mathrm{OH} \\
1\end{array}$ \\
\hline $\begin{array}{c}\operatorname{Abg}(\beta-G l c / G a l) \\
(\mathrm{GH} 1)\end{array}$ & 0.0003 & 0.0175 & 0.0010 & 0.0012 & 0.0035 & 0.077 & 7.7 \\
\hline $\begin{array}{c}\text { Bovine liver } \\
(\beta-G a l) \\
(\mathrm{GH} 35)\end{array}$ & 0.0005 & 0.0014 & 0.1167 & 0.0053 & 0.102 & 0.137 & 0.87 [16] \\
\hline $\begin{array}{c}\text { Fabrazyme }(\alpha-\mathrm{Gal}) \\
(\mathrm{GH} 27)\end{array}$ & n.i. & n.i. & n.i. & 238.1 & n.i. & n.i. & n.i. \\
\hline $\begin{array}{l}\text { S. cer. }(\alpha-\text { Glc }) \\
(\mathrm{GH} 13)\end{array}$ & n.i. & n.i. & n.i. & n.i. & n.i. & 22.5 & n.i. \\
\hline $\begin{array}{c}\text { GCase }(\beta-G l c) \\
(G H 30)\end{array}$ & 0.003 & 1.2 & 0.0639 & 0.0193 & 22.6 & 3.0 & 83 \\
\hline $\begin{array}{c}\beta-\text {-Gal human } \\
\text { lys. (GH35); IC } \mathrm{IC}_{50}\end{array}$ & 0.094 & 0.38 & 0.42 & 0.40 & 82.5 & 34.9 & 0.51 \\
\hline
\end{tabular}


Inspection of the structures of complexes with a bacterial GH35 $\beta$-galactosidase (see below) reveals an exquisite set of interactions between the active site residues and the polar groups of 22 , including a potentially electrostatic interaction between the catalytic nucleophile, Glu349, and the ring nitrogen. Most of these interactions are essentially replicated in the complex with 17. Importantly, in the absence of an endocyclic nitrogen partner, Glu 349 now forms a strong interaction with the hydroxyl group at $\mathrm{C}-2$, the secondary carbon adjacent to the alkylamine substituent on the ring. The importance of this interaction is clearly seen in comparing the $K_{i}$ value of the GH35 bovine $\beta$-galactosidase with 17 and 31. These inhibitors differ only in the presence of the hydroxyl group at that position, and indeed 31 binds some 20 fold less tightly, corresponding to an approximate $2 \mathrm{kcal} / \mathrm{mol}$ difference. An even bigger 200 fold affinity difference is seen for the human lysosomal $\beta$-galactosidase (GH35), implying crucial interactions of this particular hydroxyl group with GH35 enzymes. The substitution of a fluorine at that position rather than a hydroxyl group has similarly negative consequences. In the cases of both the mammalian $\beta$-galactosidases, the fluorine analogue binds in similar ranges as the parent with a hydrogen at that position but more than 12 times (bovine liver) to approx. 90 times (human lysosomal) worse than the hydroxylated version, implying highly reduced stabilizing interaction at that position. Binding to the GH1 and GH2 bacterial glycosidases is also considerably worse, by 64 and approx. 500 fold respectively, when compared to inhibitor 17. Since the (minimal) size difference of $F$ vs. $H$ is unlikely to result in such significant changes, a destabilizing dipolar interaction of the C-F-system with a dipole in the active site is the most probable root cause. Indeed the crystal structure reveals that this could arise from unfavorable interactions of the fluorine atom with the carboxylate group of Glu349, since no hydrogen bond like that seen with the hydroxyl of $\mathbf{1 7}$, can be formed. The strongly electron-withdrawing effect of the fluorine atom may also cause a significant reduction of the amine's basicity (when compared to parent compound 17 and the more basic deoxy derivative 31), which in turn could affect binding.

\subsection{Inhibitor Binding in Crystal Structures of a Model $\beta$-Galactosidase from Cellvibrio Japonicus}

Based on X-ray crystallographic studies of compounds 1, 14, 16, 17 as well as 22 and 31 in complex with Cellvibrio japonicus $\beta$-galactosidase (CjGH35), a tractable bacterial model which shows around $27 \%$ sequence identity with the human enzyme, notably conserved active centers, intensities of inhibition and chaperoning properties, may be partially rationalized (Figure 4).

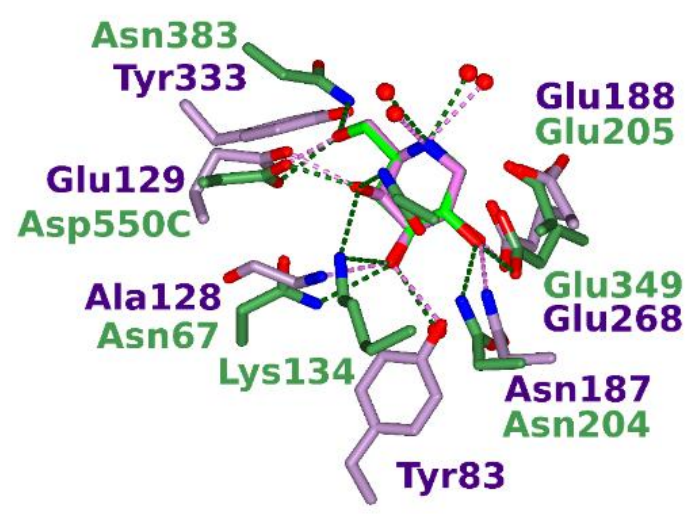

Figure 4. Overlay of DGJ in structures with human $\beta$-gal and CjGH35. Side-chains, and main-chain for Ala128 in human $\beta$-gal, forming hydrogen bonds (shown as dashed lines) with DGJ in 3THD.pdb and 4D1J.pdb respectively are shown, as well as the catalytic acid/base residues (Glu188 and 205 respectively). NB Active sites are from molecules A, but Asp550 is from molecule C in CjGH35. C atoms are colored lilac for human $\beta$-gal and lawn green for CjGH35 (with ligand $\mathrm{C}$ atoms in orchid and green respectively). The label for Asn135 for CjGH35 is omitted for clarity. Figure was made using CCP4mg [60]. 
Figure 4 shows an overlay of the ligand molecules in the X-ray structures for human lysosomal $\beta$-D-galactosidase (human $\beta$-gal) and CjGH35 complexed with 1-deoxygalactonojirimycin (3THD.pdb and $4 \mathrm{D} 1 \mathrm{~J} . \mathrm{pdb}$ respectively). The catalytic residues lie in a similar position in the two structures, with the nucleophiles (Glu268 and Glu349) accepting a hydrogen bond from the ligand 2-OH group. Both enzymes also feature an asparagine adjacent to the acid/base (at 187 and 204 respectively), which interacts with the 2-OH via its ND2 group, and a carboxyl group which tethers the 4-OH and $6-\mathrm{OH}$ groups (in human $\beta$-gal this is from Glu129, which is on a loop in the TIM barrel domain, whereas in the CjGH35 crystal this is provided by Asp550 in the C-terminal domain of an adjacent protein chain). For the inhibitors studied here, the ligand sugar moieties have clear density in all the active sites and overlay with ring $C$ atoms 2 to 5 in similar positions (Figure 5). Figure 5 displays hydrogen bonding interactions between amino acid residues in the active site of CjGH35 and ligands 1, 14, 16, 17, 22 as well as 31 respectively. The side-chains of Asn135 (which forms hydrogen bonds of 3.0 $\AA ̊$ from ND2 to C4-OH) and of Asp550E have been omitted for clarity.
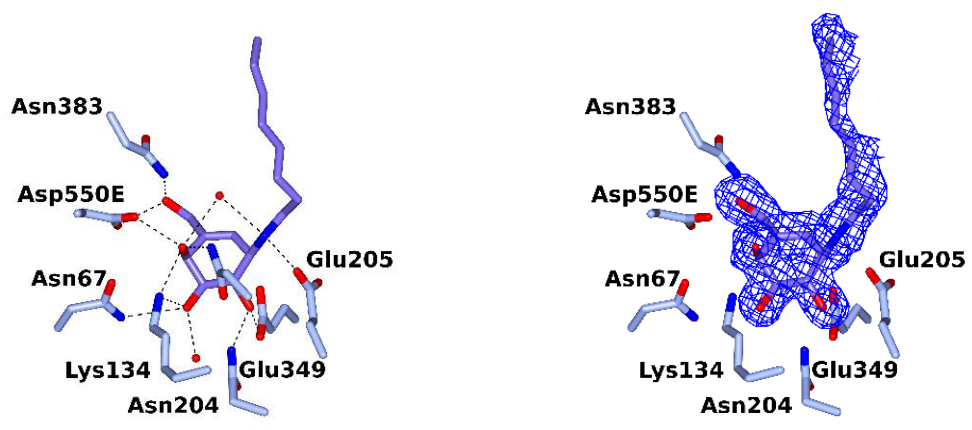

Compound 1.
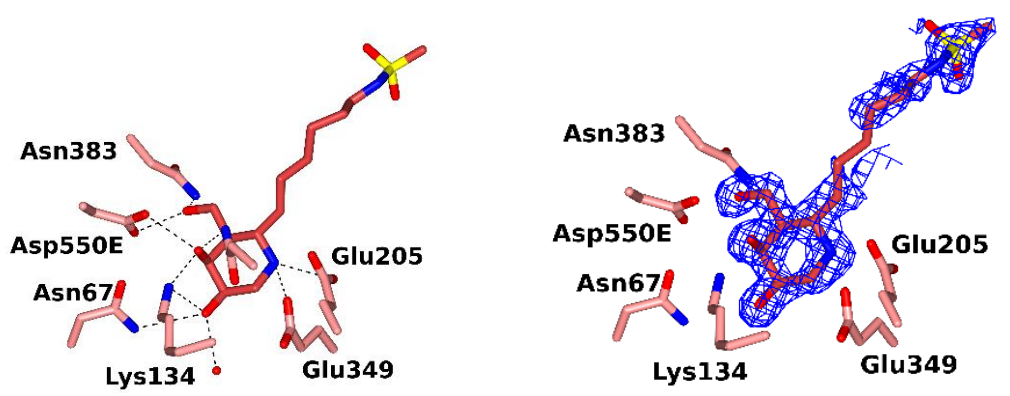

Compound 14.
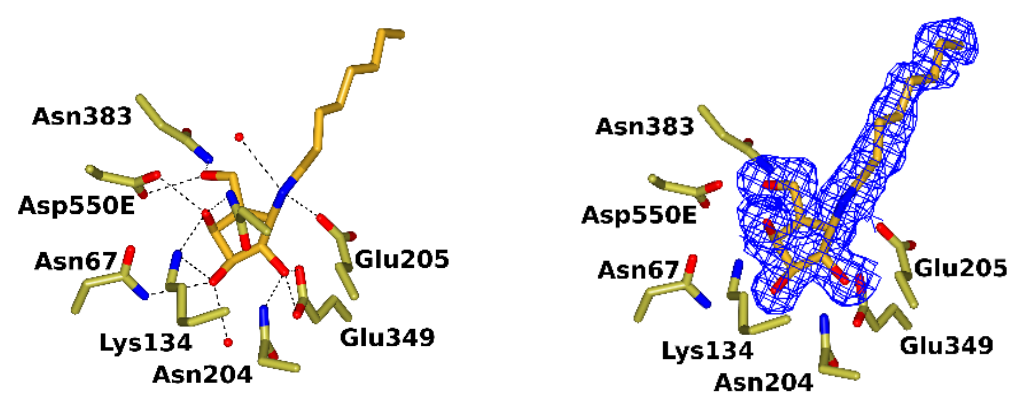

Compound 16.

Figure 5. Cont. 

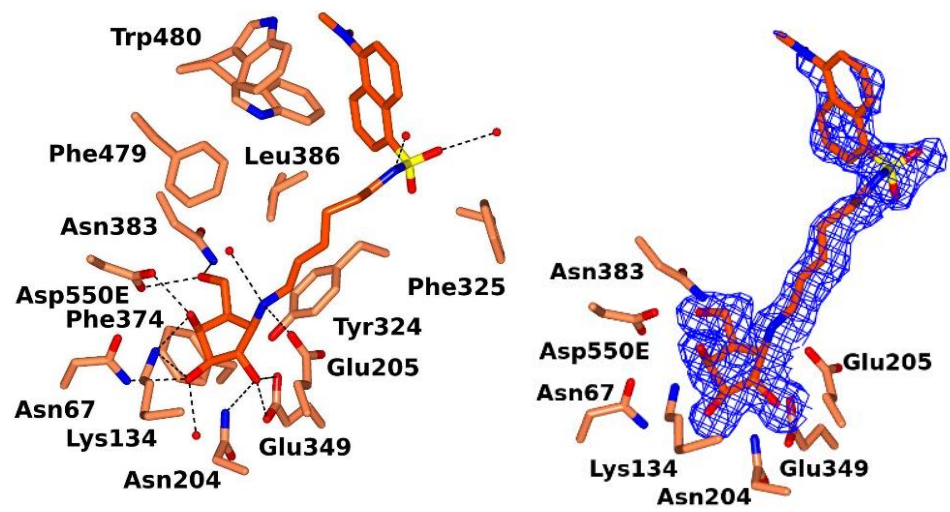

Compound 17.
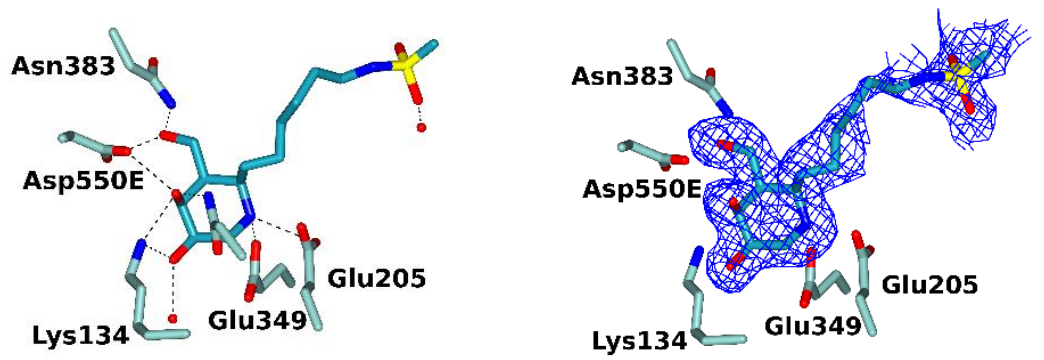

Compound 22.
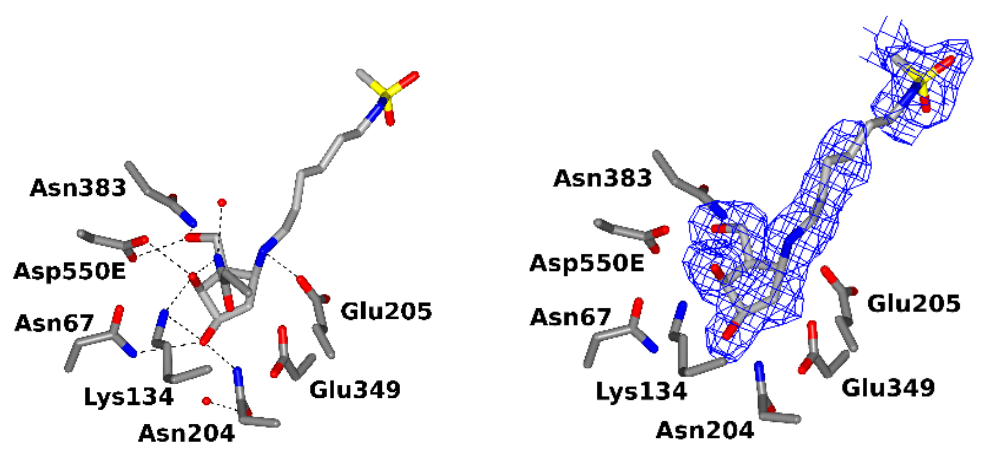

Compound 31.

Figure 5. Illustration of ligand complexes with CjGH35, showing hydrogen-bonding interactions (as dashed lines) between the modelled ligand atoms and protein side-chains, and ligand electron density (calculated as omit difference density maps contoured at $2 \mathrm{rmsd}$ ). For 17, side-chains involved in aromatic interactions within $3.8 \AA$ of the NH-dansyl group are also shown. The side-chain of Asn135 is omitted from the interactions figure for $\mathbf{1 7}$, and the electron density pictures to aid clarity.

For all the C-1-substituents in 1, 16, 17 and 31, (an NH-octyl group in 1 and 16, and $\mathrm{NH}-\mathrm{C}_{6}-\mathrm{NH}$-dansyl groups in 17 and 31), and the $\mathrm{C}-5 \mathrm{a}$-substituted $\mathrm{NH}-\mathrm{C}_{6}-\mathrm{NH}$-dansyl groups in 14 and 22, there are very few interactions between the protein and substituted derivative moieties. The $\mathrm{NH}-\mathrm{C}_{6}-\mathrm{NH}$-dansyl group was only able to be modelled for $\mathbf{1 7}$, and only at an occupancy of 0.5 . For molecules 14, 22 and 31 there is no electron density for the 5-(dimethylamino)naphthalene moiety. The active site residues are similarly oriented in all of the structures, with slight differences for $\mathbf{3 1}$, as mentioned below.

The most salient variation in hydrogen bonding occurs at the 2-OH group, which is present in 1, 16 and 17. The group is tethered by interactions with ND2 Asn204 (all 2.8-3.0 $⿱$ ) and to both OE 
atoms of Glu349 (2.6-2.7 $\AA$ ) Hydrogen bonding patterns for $\mathbf{1 6}$ and $\mathbf{1 7}$ are very similar, despite the different groups bound at $\mathrm{C}-1$, which are probably flexible and show few polar interactions with the protein, and not surprisingly, the $K_{\mathrm{i}}$ values determined for these inhibitors with recombinant human lysosomal $\beta$-Gal are very similar. Ligand $\mathbf{3 1}$ is identical to $\mathbf{1 7}$ apart from lacking a hydroxyl group at C-2, the importance of which is reflected in a much poorer $K_{\mathrm{i}}$ value (200-fold worse for human lysosomal $\beta$-galactosidase). There are two other differences in the ligand interactions of $\mathbf{3 1}$ (not only from those seen for 17, but also from the other complexes studied here). Firstly, there is a hydrogen bond from the C-3 hydroxyl to ND2 Asn204, in addition to the three hydrogen bonds to Asn67, Lys134 and a water molecule (which is hydrogen bonded to OD1 Asn204 and OE1 Gln64). Secondly, there is a shift in the position of Gln64, with the NE2 atom forming a hydrogen bond to O Ala348, instead of the OE1 interacting with a water which is hydrogen bonded between O Thr65 and ND2 Asn67 (as seen in the other structures). These probably play a far lesser contribution to the weaker $K_{\mathrm{i}}$ values than the absence of three potential hydrogen bonds from a $\mathrm{C}-2-\mathrm{OH}$ group.

Another key ligand-protein interaction is displayed for compounds 1, 16, 17 and 31, which feature hydrogen bonding interactions from their amine groups at ring position 1 to Glu205 (2.6-2.8 $)$ and with a water which is also hydrogen bonded to ND2 Asn135, and in the case of $\mathbf{1}$, to the C-4 hydroxyl group. While there is no equivalent group for $\mathbf{1 4}$ and 22, the Glu205 side-chain is oriented similarly in all of the structures despite the lack of hydrogen bonds with a C-2 hydroxyl group for $\mathbf{1 4}$ as well as 22 and 31. The position of Glu205 may be maintained by an additional hydrogen bond from its OE1 atom to a water which is also hydrogen-bonded to $\mathrm{OH}$ Tyr209.

In contrast to the carbacyclic compounds, $\mathbf{1 4}$ and 22 have a nitrogen atom in position 1 of the ring. The sugar conformation is close to ${ }^{\prime 4} \mathrm{C}_{1} "\left(={ }^{4} \mathrm{C}_{\mathrm{N}}\right)$ in both, and the $\mathrm{N}$ of the isofagomine moiety is hydrogen bonded to Glu205 and Glu349, which may compensate for the lack of interactions from an $\mathrm{NH}$ group at the start of the hydrocarbon chain seen for compounds 1, 16, 17 and 31. The absence of a C-2-position hydroxyl group will increase the basicity of the $\mathrm{N}$ atom, allowing it to also form electrostatic interactions with Glu349. In the structure with 22 the $\mathrm{N}$ atom points more steeply downwards away from the plane of the ring forming a closer hydrogen bond with OE1 Glu349 than for 14 (2.5-2.6 $\AA$ for all of the molecules in the asymmetric unit, as opposed to $2.6-2.8 \AA$ for 14). This may contribute to the better inhibition observed for $\mathbf{2 2}$ than for $\mathbf{1 4}$ with all the galactosidases tested.

In $\mathbf{1}$, which is known to be a powerful $\beta$-galactosidase inhibitor, the sugar conformation is closer to ${ }^{4} \mathrm{H}_{3}$, probably because of the double bond between $\mathrm{C}-5$ and $\mathrm{C}-5 \mathrm{a}$, and reflecting that the $\mathrm{C}$ in ring position 2 is not attracted downwards towards the catalytic Glu residues in the same way as for the isofagomine $\mathrm{N}$ atom in $\mathbf{1 4}$ and $\mathbf{2 2}$.

Overlays of the compared ligand structures and active sites are shown in Figure 6.

\subsection{Chaperoning Activities}

Chaperoning activities of compounds with $\mathrm{G}_{\mathrm{M} 1}$-gangliosidosis and Morquio B related cell lines are outlined in Figures 7 and 8. Cells with the R201C mutant of $\beta$-galactosidase which is related to juvenile $\mathrm{G}_{\mathrm{M} 1}$-gangliosidosis and has previously been shown to be amenable to chaperone 1 reacted very positively to isofagomine derivatives 11,14 and 22 as well as to cyclopentanoid ligands 16 and 17 . The corresponding deoxy derivative 31 exhibited distinctly reduced chaperoning activity and was only trailed by deoxyfluoro analog 37 . Incubation of the cells with compounds 31 and 37, respectively, up to $10 \mu \mathrm{M}$ had no notable influence on $\beta$-galactosidase activity and cell viability. Higher concentrations of these inhibitors led to decreased enzyme activity and to a complete arrest of cell growth over the incubation time. Concentrations of more than $100 \mu \mathrm{M}$ resulted in dramatic loss of both, $\beta$-galactosidase activity as well as cell viability. 

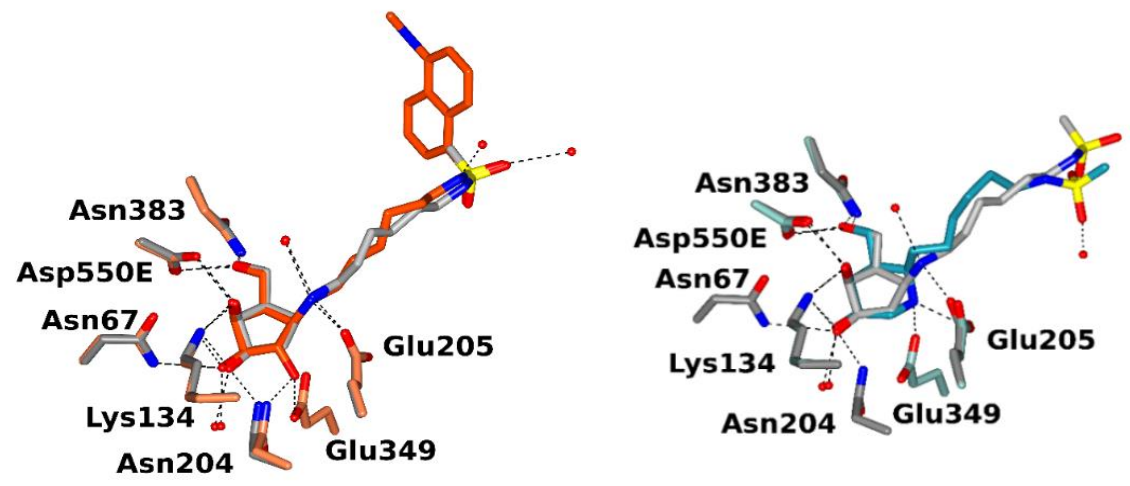

Overlay of compounds 17 and 31 (left), as well as 22 and 31 (right).
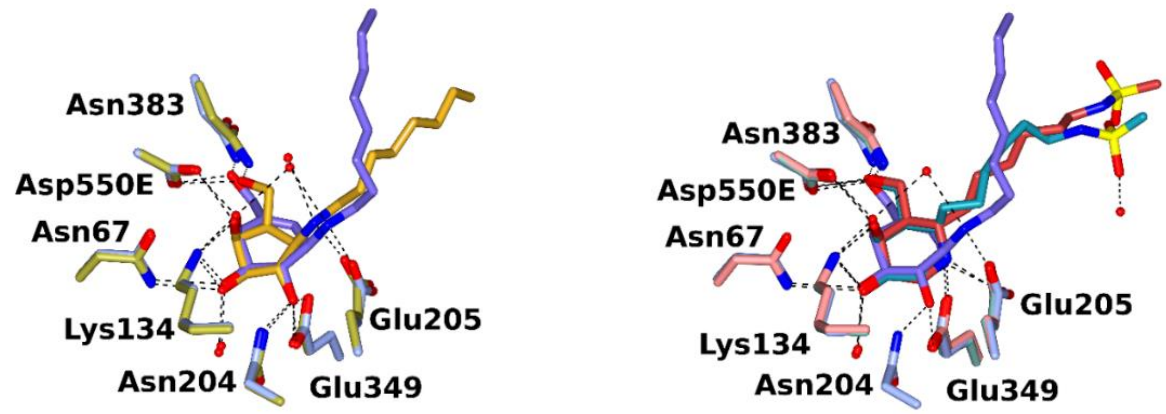

Overlay of compounds 1 and 16 (left), as well as 1, 14 and 22 (right).
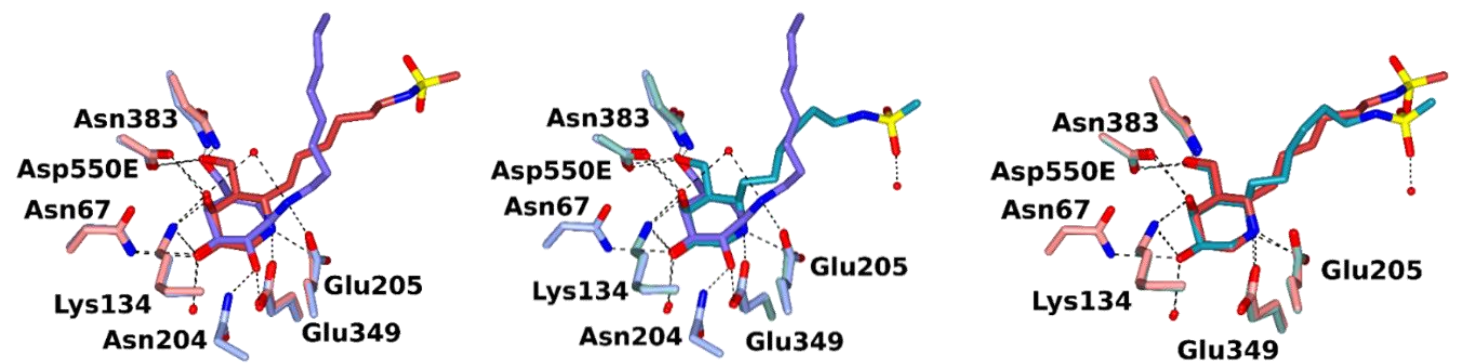

Overlay of compounds 1 and 14 (left), 1 and 22 (middle), as well as 14 and 22 (right).

Figure 6. Overlay of inhibitors.

With $\mathrm{R} 201 \mathrm{H} / \mathrm{H} 281 Y$ (adult $\mathrm{G}_{\mathrm{M} 1}$-gangliosidosis), both structural types, 11 as well as 17, show $\beta$-gal activity increases of 6- to 7-fold at $0.1 \mu \mathrm{M}$ and 9- to 10-fold at $1 \mu \mathrm{M}$ with slight advantages for isofagomine derivative 11. For comparison, the maximum effect of carbasugar $\mathbf{1}$ ( 6.8 -fold increase) is clearly shifted to higher chaperone concentrations of 10-25 $\mu \mathrm{M}$ (Figure 7).

With C230R/C230R (late infantile $\mathrm{G}_{\mathrm{M} 1}$-gangliosidosis), chaperoning maxima were reached at $1 \mu \mathrm{M}$ with 4-epi-isofagomine $\mathbf{1 1}$ (12-fold) and between 1 and $10 \mu \mathrm{M}$ (7-fold) with carbacycle $\mathbf{1 7}$ (NOEV, 1, 6.4-fold). The Morquio B/ $\mathrm{G}_{\mathrm{M} 1}$-gangliosidosis mutation R201H/S149F exhibits comparable sensitivities to all three chaperones screened, with small advantage for NOEV (1, $\geq 10$-fold), followed by $\mathbf{1 1}$ (9.5-fold) and 17 (9-fold). Interestingly, with $\mathrm{Y} 333 \mathrm{H} / \mathrm{Y} 333 \mathrm{H}$ (juvenile $\mathrm{G}_{\mathrm{M} 1}$-gangliosidosis), carbacycle $\mathbf{1 7}$ is the most potent chaperone with a maximum activity of nearly 9-fold at $10 \mu \mathrm{M}$, followed by NOEV (1, nearly 8-fold at $25 \mu \mathrm{M}$ ) and $\mathbf{1 1}$ (5-fold at $25 \mu \mathrm{M}$ ). None of the three chaperones probed showed any chaperone activity with Y270D/Y270D and G438E/G438E, respectively. The compounds had no inhibitory effects on human lysosomal hexosaminidase in the concentration range probed (Figure 8). 


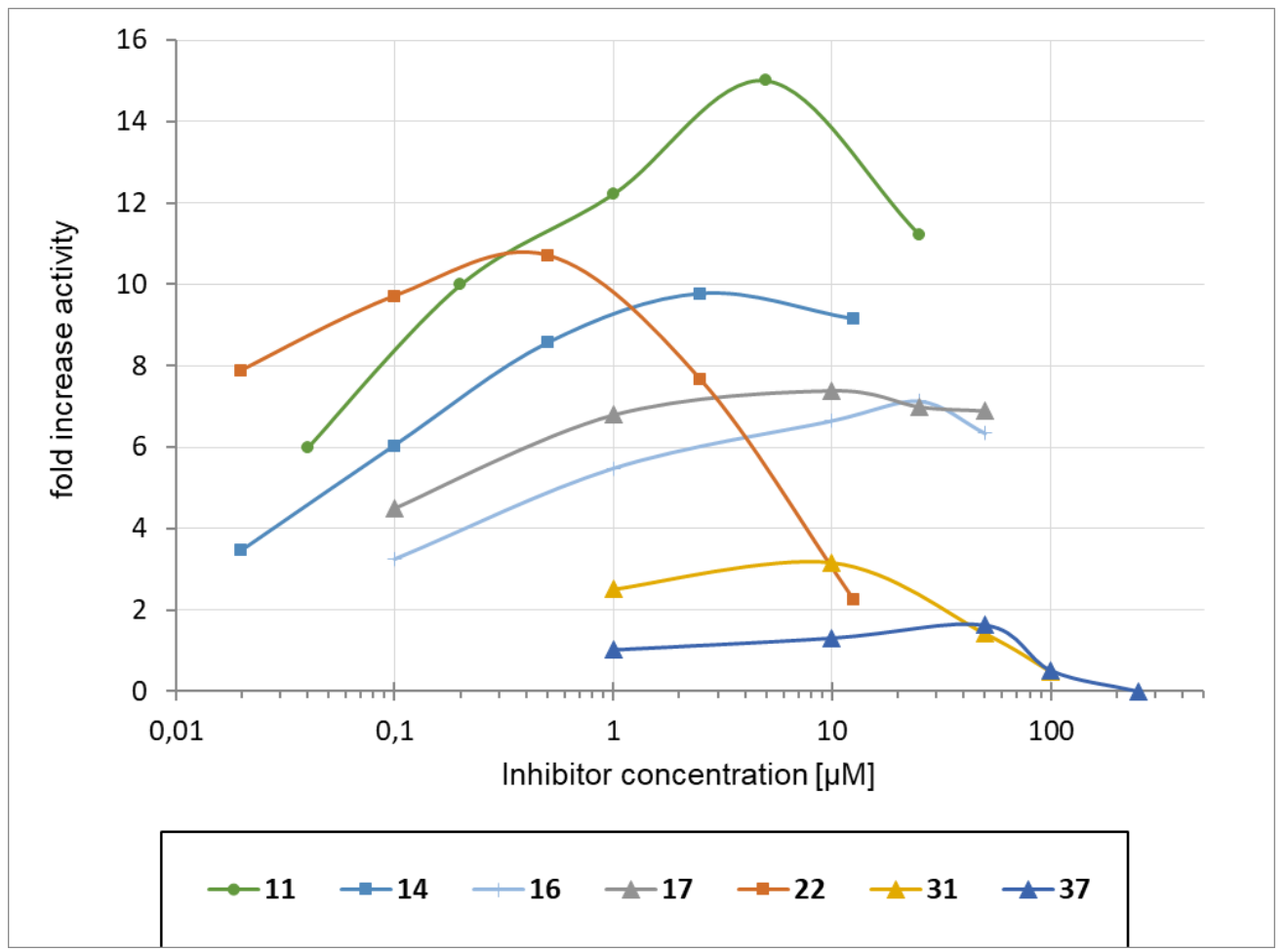

Figure 7. Activity enhancements of R201C mutant lysosomal $\beta$-galactosidase with compounds 11, 14, $16,17,22,31$ and 37 .

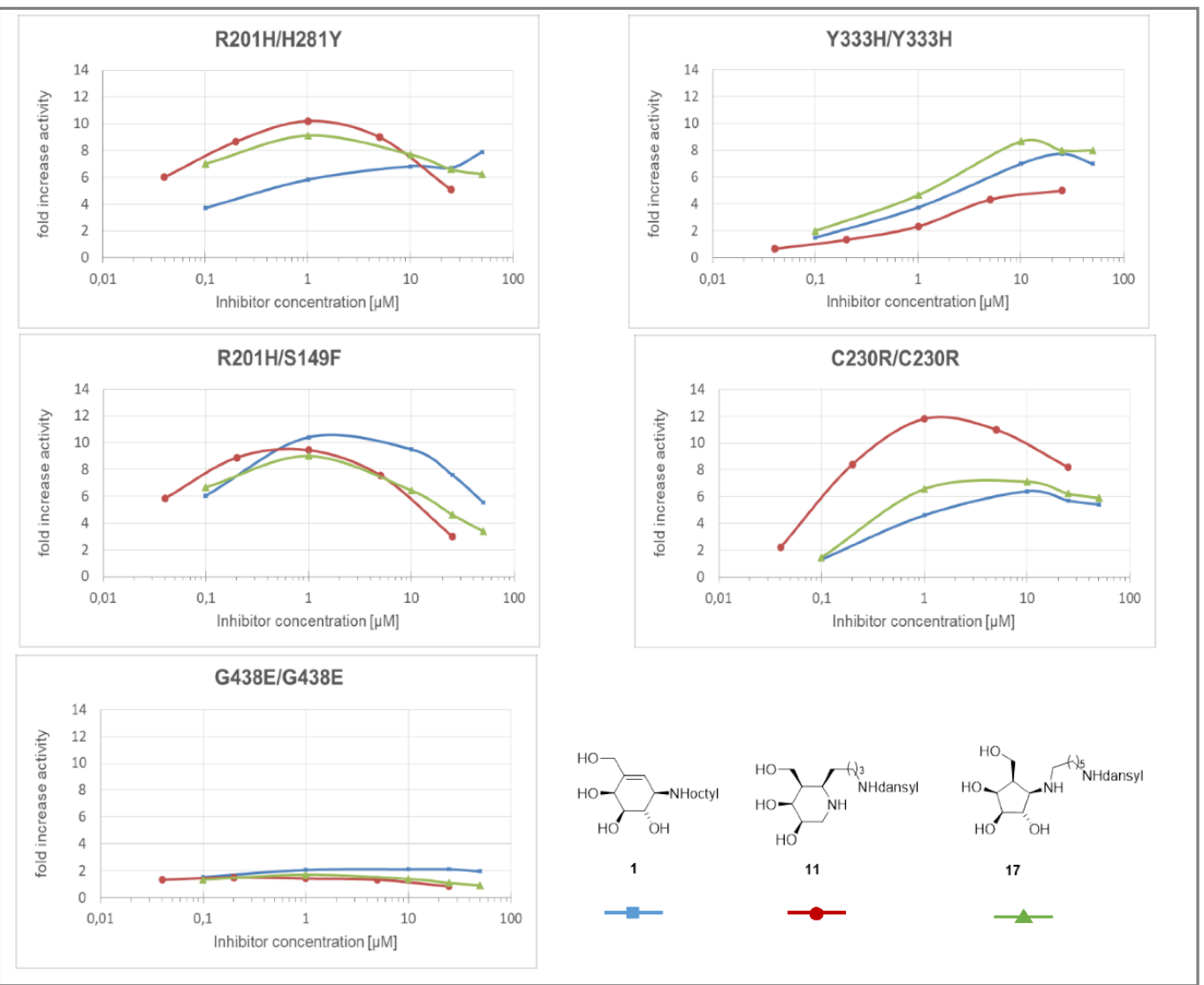

Figure 8. Activity enhancements of various lysosomal $\beta$-galactosidase mutants with compounds 1, 11, 17. 


\section{Discussion}

Two types of structurally very different but similarly potent $\beta$-galactosidase inhibitors, the C-5-chain extended 4-epi-isofagomines (14 and 22) as well as D-galacto configured aminohydroxymethyl-cyclopentane derivatives 17, 31 and 37 were investigated concerning their properties as pharmacological chaperones for selected $\mathrm{G}_{\mathrm{M} 1}$-gangliosidosis as well as Morquio B cell lines. To gain more in-depth insights into structural requirements for good inhibition and chaperoning, an important hydroxyl group in the cyclopentanoid series was substituted. Removal of this secondary alcohol was expected to provide isofagomine-like improved activity through increase of the amine's basicity whereas its substitution with a fluorine atom was exploited to probe hydrogen bonding with the amino acid residues in and around the active site.

New inhibitor 22 turned out to be highly potent and exhibited encouraging dose-dependent chaperoning profiles with enzyme mutant R201C. For the cyclopentanoid chaperones, on the other hand, OH-2 appears to be a vital feature for their activity as inhibitors and pharmacological chaperones, since its absence and the concomitantly increased basicity of the adjacent amine apparently cannot compensate for the reduced number of interactions with amino acid residues resulting from the removal of this particularly crucial functional group.

Notably, despite indisputable biochemical evidence based on quite a few inhibitors probed [41,46,47,55,61-64], the frequently observed synergistic inhibitory effect of the terminal dansyl amide could not be correlated to additional specific binding events of this moiety to the protein as was implied by the lack of electron density for this substituent in the bacterial model enzyme-inhibitor complexes examined.

Furthermore, it is interesting to note that the five $\beta$-galactosidase mutants investigated (Figure 8) exhibit distinctly different susceptibilities towards the three classes of chaperones screened. Whereas for R201H/H281Y and, in particular, C230R/C230R the isoimino sugars (for example 11) are clearly the most efficient chaperones across the entire concentration range probed, cyclopentane 17 shows clear advantage over pyranoid carbasugar 1 as well as piperidine 11 with $\mathrm{Y} 333 \mathrm{H} / \mathrm{Y} 333 \mathrm{H}$, and in the case of R201H/S149F, carbasugar NOEV (1), turned out to be the most potent chaperone for this particular mutant. Thus, for the development of effective pharmacological chaperones, the individual mutant under scrutiny should be screened with a representative range of suitable ligand types for optimized chaperoning efficacy.

\section{Experimental}

\subsection{Synthetic Section}

XRD data and NMR spectra for new compounds are all in the Supplementary Materials. Optical rotations were measured at $20{ }^{\circ} \mathrm{C}$ on a Perkin Elmer 341 polarimeter (Perkin Elmer, Waltham, MA, USA) at a wavelength of $589 \mathrm{~nm}$ and a path length of $10 \mathrm{~cm}$. NMR spectra were recorded on a Varian INOVA 500 (Varian, Palo Alto, CA, USA) operating at $499.82 \mathrm{MHz}\left({ }^{1} \mathrm{H}\right), 470.3 \mathrm{MHz}\left({ }^{19} \mathrm{~F}\right)$ and at 125.894 MHz $\left({ }^{13} \mathrm{C}\right)$ or on a Bruker (Billerica, MA, USA) Ultrashield spectrometer at $300.36\left({ }^{1} \mathrm{H}\right)$ and $75.53\left({ }^{13} \mathrm{C}\right) \mathrm{MHz}$, respectively. $\mathrm{CDCl}_{3}$ was employed for protected compounds and methanol- $d_{4}$ or $\mathrm{D}_{2} \mathrm{O}$ for unprotected inhibitors. Carbon and hydrogen numbering in NMR spectra was conducted in analogy to carbohydrate nomenclature and clockwise, starting with the amino bearing carbon as C-1 (Numbering pattern for cyclopentanes shown in Figure 2). Chemical shifts are listed in delta employing residual, non-deuterated solvent as the internal standard. Signals were assigned unambiguously by COSY, HSQC as well as APT analysis. For the sake of simplicity and comparison, carbohydrate numbering has been applied to the hydroxymethyl cyclopentane series throughout this work. This may be accounted for by the fact that these compounds can be regarded "monosaccharide derivatives" resulting from formal homolytic extrusion of the ring oxygen. Stereochemical features remain the same as in the respective parent sugar. The signals of the aromatic groups are located in the expected regions and are not listed explicitly. The signals of the protecting groups as well as of the $N$-substituents 
were found in the expected regions and are only listed explicitly when overlapping with important spectral features of the respective compound. Due to stable rotameric populations of the N-Boc group, signal splitting in the respective NMR spectra has been observed leading to somewhat poor resolution of the ${ }^{1} \mathrm{H}-\mathrm{NMR}$ and ${ }^{13} \mathrm{C}-\mathrm{NMR}$ spectra. Signals of $N$-Boc protected compounds may be retarded or show up as pairs. For crucial intermediate 33, the structure was confirmed by XRD structural analysis: Suitable single crystals of compounds were immersed in silicone oil, mounted using a glass fiber and frozen in the cold nitrogen stream $(100 \mathrm{~K})$. X-Ray diffraction data were collected at low temperature on a Bruker Kappa APEX II diffractometer using Mo $K_{a}$ radiation $(1=0.71073 \AA)$ generated by an INCOATEC micro-focus source. The data reduction and absorption correction was performed with the Bruker SMART (Bruker AXS Inc., Madison, WI, USA) and Bruker SADABS (Bruker AXS Inc., Madison, Wisconsin, USA), respectively. The structures were solved with SHELXT [65] by direct methods and refined with SHELXL by least-square minimization against $F^{2}$ using first isotropic and later anisotropic thermal parameters for all non-hydrogen atoms. Hydrogen atoms were added to the structure models on calculated positions using the riding model. The space group assignments and structural solutions were evaluated using PLATON [66,67].

MALDI-TOF Mass Spectrometry was performed on a Micromass TofSpec 2E Time-of-Flight Mass Spectrometer (Waters Corporation, Milford, MA, USA). Analytical TLC was performed on precoated aluminum plates silica gel 60 F254 (E. Merck 5554, E. Merck, Darmstadt, Germany) and detected with UV light $(254 \mathrm{~nm})$. For staining, a solution of vanillin $(9 \mathrm{~g})$ in a mixture of $\mathrm{H}_{2} \mathrm{O}(950 \mathrm{~mL}) / \mathrm{EtOH}$ $(750 \mathrm{~mL}) / \mathrm{H}_{2} \mathrm{SO}_{4}(120 \mathrm{~mL})$ or ceric ammonium molybdate $(100 \mathrm{~g}$ ammonium molybdate/8 g ceric sulfate in $10 \% \mathrm{H}_{2} \mathrm{SO}_{4}(1 \mathrm{~L})$ ) were employed followed by heating on a hotplate. For column chromatography, silica gel 60 (230-400 mesh, E. Merck 9385) or silica gel 60 (Acros Organics, AC 24036, Thermo Fisher Scientific Inc., Waltham, MA, USA) were used.

\section{6-[(5aR)-(N-tert-Butyloxycarbonyl-3,4-O-isopropylidene-6-O-methoxymethylene-4-epi- isofagomin-5a-yl)-hex-4-enoic nitrile (19)}

A solution of freshly prepared LDA [by dropwise addition of $2.5 \mathrm{M} n$-BuLi $(2.0 \mathrm{~mL})$ in hexane to diisopropyl amine $(0.18 \mathrm{~mL}, 1.3 \mathrm{mmol}, 20 \%$ solution in dry THF)] in dry THF was added dropwise at $-78{ }^{\circ} \mathrm{C}$ under an atmosphere of nitrogen to a suspension of triphenyl-(3-cyano)propylphosphonium bromide $\left(557 \mathrm{mg}, 1.36 \mathrm{mmol}\right.$ ). After stirring at $-40^{\circ} \mathrm{C}$ for $60 \mathrm{~min}$, a solution of aldehyde 18 (ref. [46,47], $150 \mathrm{mg}, 0.39 \mathrm{mmol}$, dissolved in $2 \mathrm{~mL}$ dry THF) was added dropwise. After having been stirred for $12 \mathrm{~h}$, the reaction mixture was diluted with $\mathrm{CH}_{2} \mathrm{Cl}_{2}$ and consecutively washed with $\mathrm{HCl}(6 \%)$ and saturated $\mathrm{NaHCO}_{3}$. After drying over $\mathrm{Na}_{2} \mathrm{SO}_{4}$, the filtrate was concentrated under reduced pressure to provide the crude product. Chromatographic purification (cyclohexane-EtOAc 20:1 to cyclohexane-EtOAc 10:1) afforded nitrile $19(110 \mathrm{mg}, 0.25 \mathrm{mmol}, 66 \%)$ as a mixture of the $E / Z$-isomers. ${ }^{1} \mathrm{H} \mathrm{NMR}(300 \mathrm{MHz}$, $\left.\mathrm{CD}_{3} \mathrm{OD}\right): \delta=5.40$ (bs, $\left.2 \mathrm{H}, \mathrm{H}-2^{\prime}, \mathrm{H}-3^{\prime}\right), 4.63-4.55$ (m, $\left.2 \mathrm{H}, \mathrm{O}-\mathrm{CH}_{2}-\mathrm{O}-\mathrm{CH}_{3}\right), 4.47-3.80$ (m, $4 \mathrm{H}, \mathrm{H}-2 \mathrm{eq}$, H-3, H-4, H-5a), 3.60 (m, 2 H, H-6a, H-6b), 3.33-3.28 (m, 3 H, O-CH $\left.-\mathrm{C}_{2}-\underline{\mathrm{H}}_{3}\right), 2.62$ (m, $2 \mathrm{H}, \mathrm{H}-2 \mathrm{ax}$, H-1'a), 2.45-2.01 (m, 6 H, H-5, H-1'b, H-4' a, H-4'b, H-5'a, H-5'b), 1.47 (s, 3 H, C( $\left.\left.\underline{\mathrm{CH}}_{3}\right)_{2}\right), 1.38$ (s, 9 H, $\left.\mathrm{N}-\mathrm{CO}-\mathrm{C}\left(\mathrm{CH}_{3}\right)_{3}\right), 1.27\left(\mathrm{~s}, 3 \mathrm{H}, \mathrm{C}\left(\mathrm{CH}_{3}\right)_{2}\right) ;{ }^{13} \mathrm{C} \mathrm{NMR}\left(75.5 \mathrm{MHz}, \mathrm{CD}_{3} \mathrm{OD}\right): \delta=154.7,154.4\left(\mathrm{~N}-\mathrm{CO}-\mathrm{C}\left(\mathrm{CH}_{3}\right)_{3}\right)$, 129.7-126.7 (C-2', C-3'), 119.1, $119.0\left(\mathrm{C}-6^{\prime}\right), 109.2,109.2\left(\underline{\mathrm{C}}\left(\mathrm{CH}_{3}\right)_{2}\right), 96.6,96.5\left(\mathrm{O}-\mathrm{CH}_{2}-\mathrm{O}_{-}-\mathrm{CH}_{3}\right), 80.6$, $79.9\left(\mathrm{~N}-\mathrm{CO}-\underline{\mathrm{C}}\left(\mathrm{CH}_{3}\right)_{3}\right), 73.0,72.9,71.0,70.4$ (C-3, C-4), 66.3, $65.9(\mathrm{C}-6), 55.4,55.3\left(\mathrm{O}-\mathrm{CH}_{2}-\mathrm{O}-\mathrm{CH}_{3}\right), 50.5$, 49.3 (C-5a), 40.2, 39.8, 39.3, 38.9 (C-2, C-5, C-4'), 29.7, 29.8, 28.7, 28.3, $25.9\left(\mathrm{~N}-\mathrm{CO}-\mathrm{C}\left(\mathrm{CH}_{3}\right)_{3}, \mathrm{C}\left(\mathrm{CH}_{3}\right)_{2}\right)$, 23.6, 23.3, $17.4\left(\mathrm{C}-1^{\prime}, \mathrm{C}-4^{\prime}, \mathrm{C}-5^{\prime}\right)$. MS (MALDI): Calcd for $\left[\mathrm{C}_{22} \mathrm{H}_{36} \mathrm{~N}_{2} \mathrm{O}_{6} \mathrm{Na}\right]^{+}: m / z 447.2471[\mathrm{M}]^{+}$; Found $[\mathrm{M}]^{+} 447.2468$.

\section{(5aR)-N-tert-Butyloxycarbonyl-5a-C-(6-amino)hexyl-3,4-O-isopropylidene-6-methoxymethylene-} 4-epi-isofagomine (20)

A $10 \%$ solution of the nitrile 19 (110 mg, $0.25 \mathrm{mmol}$ ) in $\mathrm{MeOH}$ was stirred with Raney-Ni (moist in $\mathrm{H}_{2} \mathrm{O}$ ) under an atmosphere of $\mathrm{H}_{2}$ at ambient pressure for $60 \mathrm{~min}$. After completed conversion of the starting material, the catalyst was filtered off. Removal of the solvent, followed by purification on silica 
gel $\left(\mathrm{CHCl}_{3}-\mathrm{MeOH} 8: 1+1 \mathrm{vol} \% \mathrm{NH}_{4} \mathrm{OH}(25 \%)\right)$ provided amine $20(92 \mathrm{mg}, 0.21 \mathrm{mmol}, 84 \%)$ as a yellow syrup. $[\alpha]_{\mathrm{D}}^{20}:-1.2\left(c\right.$ 2.6, MeOH); ${ }^{1} \mathrm{H}$ NMR $\left(300 \mathrm{MHz}, \mathrm{CD}_{3} \mathrm{OD}\right): \delta=4.66-4.63\left(\mathrm{~m}, 2 \mathrm{H}, \mathrm{O}-\mathrm{C}_{2}-\mathrm{O}_{-} \mathrm{CH}_{3}\right)$, 4.32 (m, 2 H, H-4, H-5a), 4.13-3.91 (m, 2 H, H-2eq, H-4), 3.39-3.35 (m, 3 H, O-CH $\left.-\mathrm{CH}_{2}-\underline{\mathrm{H}}_{3}\right), 3.68$ (m, $2 \mathrm{H}$, H-6a, H-6b), 2.82 (t, 2 H, H-6'), 2.81 (m, 1 H, H-2ax), 2.32 (m, 1 H, H-5), 2.06 (m, 1 H, H-1'a), 1.69-1.16 (m, $\left.24 \mathrm{H}, \mathrm{H}-1^{\prime} \mathrm{b}, \mathrm{H}-2^{\prime}, \mathrm{H}-3^{\prime}, \mathrm{H}-4^{\prime}, \mathrm{H}-5^{\prime}, \mathrm{C}\left(\mathrm{C}_{3}\right)_{3}, \mathrm{~N}-\mathrm{CO}-\mathrm{C}\left(\mathrm{C}_{3}\right)_{3}\right) .{ }^{13} \mathrm{C} \mathrm{NMR}\left(75.5 \mathrm{MHz}, \mathrm{CD}_{3} \mathrm{OD}\right): \delta=$

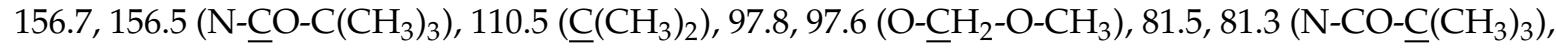

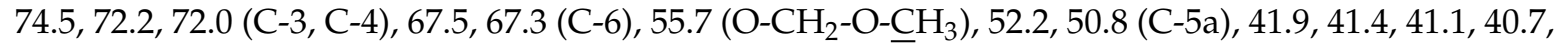
39.9 (C-2, C-5, C-6' $), 32.2-26.2\left(\mathrm{C}-1^{\prime}, \mathrm{C}-2^{\prime}, \mathrm{C}-3^{\prime}, \mathrm{C}-4^{\prime}, \mathrm{C}-5^{\prime}, \mathrm{N}-\mathrm{CO}-\mathrm{C}\left(\mathrm{CH}_{3}\right)_{3}, \mathrm{C}\left(\underline{\mathrm{CH}}_{3}\right)_{2}\right)$. MS (MALDI): Calcd for $\left[\mathrm{C}_{22} \mathrm{H}_{42} \mathrm{~N}_{2} \mathrm{O}_{6} \mathrm{Na}\right]^{+}: \mathrm{m} / z 453.2941[\mathrm{M}]^{+}$; Found [M] ${ }^{+} 453.2940$.

(5aR)-N-tert-Butyloxycarbonyl-5a-C-(6-dansylamino)hexyl-3,4-O-isopropylidene-6-Omethoxymethylene-4-epi-isofagomine (21)

To a suspension of amine 20 (92 mg, $0.21 \mathrm{mmol})$ and $\mathrm{Na}_{2} \mathrm{CO}_{3}(68 \mathrm{mg}, 0.64 \mathrm{mmol})$ in $3 \mathrm{~mL} \mathrm{MeOH}$, dansyl chloride ( $69 \mathrm{mg}, 0.26 \mathrm{mmol}$ ) was added. After completed conversion of the starting material, the reaction mixture was evaporated to dryness. Purification on silica gel (cyclohexane-EtOAc 15:1) gave partially protected dansylamide $21(86 \mathrm{mg}, 0.13 \mathrm{mmol}, 61 \%)$ as fluorescent wax. $[\alpha]_{\mathrm{D}}^{20}:+0.7(c 1.0$, $\left.\mathrm{CHCl}_{3}\right) ;{ }^{1} \mathrm{H}$ NMR $\left(300 \mathrm{MHz}, \mathrm{CDCl}_{3}\right): \delta=4.70-4.56\left(\mathrm{~m}, 2 \mathrm{H}, \mathrm{O}-\mathrm{C}_{2}-\mathrm{O}-\mathrm{CH}_{3}\right), 4.26-3.81(\mathrm{~m}, 4 \mathrm{H}, \mathrm{H}-2 \mathrm{eq}$, H-3, H-4, H-5a), 3.55 (m, 2 H, H-6a, H-6b), 3.41-3.32 (m, 3 H, O-CH $\left.-\mathrm{CH}_{2}-\underline{\mathrm{C}}_{3}\right), 2.78$ (m, 2 H, H-6'), $2.52(\mathrm{~m}, 1 \mathrm{H}, \mathrm{H}-2 \mathrm{ax}), 2.18(\mathrm{~m}, 1 \mathrm{H}, \mathrm{H}-5), 1.78\left(\mathrm{~m}, 1 \mathrm{H}, \mathrm{H}-1^{\prime} \mathrm{a}\right), 1.46\left(\mathrm{~s}, 3 \mathrm{H},\left(\mathrm{C}\left(\mathrm{C}_{3}\right)_{2}\right), 1.43(\mathrm{~s}, 9 \mathrm{H}\right.$, $\left.\mathrm{N}-\mathrm{CO}-\mathrm{C}\left(\mathrm{C}_{3}\right)_{3}\right), 1.30\left(\mathrm{~s}, 3 \mathrm{H},\left(\mathrm{C}\left(\mathrm{C}_{3}\right)_{2}\right), 1.28-0.94\left(\mathrm{~m}, 9 \mathrm{H}, \mathrm{H}-1^{\prime} \mathrm{b}, \mathrm{H}-2^{\prime}, \mathrm{H}-3^{\prime}, \mathrm{H}-4^{\prime}, \mathrm{H}-5^{\prime}\right) .{ }^{13} \mathrm{C} \mathrm{NMR}\right.$ $\left(75.5 \mathrm{MHz}, \mathrm{CDCl}_{3}\right): \delta=155.0,154.8\left(\mathrm{~N}-\mathrm{CO}-\mathrm{C}\left(\mathrm{CH}_{3}\right)_{3}\right), 109.3\left(\underline{\mathrm{C}}\left(\mathrm{CH}_{3}\right)_{2}\right), 96.7,96.6\left(\mathrm{O}_{-} \mathrm{CH}_{2}-\mathrm{O}-\mathrm{CH}_{3}\right)$,

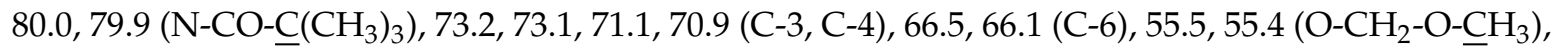
50.8, 49.5 (C-5a), 45.6 (dansyl), 43.5, 43.4 (C-6'), 40.1, 39.5, 38.8 (C-2, C-5), 29.8, 29.6 (C-1'), 28.8, $26.5\left(\mathrm{C}\left(\mathrm{CH}_{3}\right)_{2}\right), 28.7,28.6\left(\mathrm{~N}-\mathrm{CO}-\mathrm{C}\left(\underline{\mathrm{CH}}_{3}\right)_{3}\right), 27.1-26.2\left(\mathrm{C}-2^{\prime}, \mathrm{C}-3^{\prime}, \mathrm{C}-4^{\prime}, \mathrm{C}-5^{\prime}\right)$. MS (MALDI): Calcd for $\left[\mathrm{C}_{34} \mathrm{H}_{53} \mathrm{~N}_{3} \mathrm{O}_{8} \mathrm{SNa}\right]^{+}: \mathrm{m} / z 686.3451[\mathrm{M}]^{+}$; Found [M] ${ }^{+} 686.3450$.

\section{(5aR)-5a-C-(6-Dansylamino)hexyl-4-epi-isofagomine (22)}

Compound 21 ( $86 \mathrm{mg}, 0.13 \mathrm{mmol})$ was dissolved in $\mathrm{MeOH}(3 \mathrm{~mL})$ and $\mathrm{HCl}(12 \mathrm{M})$ was added dropwise to adjust $\mathrm{pH} 1$. After completed removal of all protecting groups, the solvents were removed under reduced pressure. Purification on silica gel $\left(\mathrm{CHCl}_{3}-\mathrm{MeOH} 8: 1+1 \mathrm{vol} \% \mathrm{NH}_{4} \mathrm{OH}(25 \%)\right)$ yielded free compound $22(46 \mathrm{mg}, 0.096 \mathrm{mmol}, 74 \%)$ as fluorescent wax. $[\alpha]_{\mathrm{D}}^{20}:-19.1(c 0.58, \mathrm{MeOH}),{ }^{1} \mathrm{H} \mathrm{NMR}$ (300 MHz, CD 3 OD): $\delta=3.85$ (m, 3 H, H-3, H-4, H-6a), 3.70 (dd, 1 H, J6a,6b 11.8 Hz, J5,6b 4.5 Hz, H-6b), 3.21 (m, $1 \mathrm{H}, \mathrm{H}-5 \mathrm{a}), 3.12$ (dd, $\left.1 \mathrm{H}, J_{2 \mathrm{ax}, 2 \mathrm{eq}} 12.3 \mathrm{~Hz}, J_{2 \mathrm{eq}, 3} 2.9 \mathrm{~Hz}, \mathrm{H}-2 \mathrm{eq}\right), 3.07$ (dd, $1 \mathrm{H}, J_{2 \mathrm{ax}, 3} 2.3 \mathrm{~Hz}$, H-2ax), 3.07 (t, 2 H, H-6' ), 2.01 (m, 1 H, H-5), 1.66 (m, 2 H, H-1'), 1.34-0.96 (m, 8 H, H-2' , H-3' , H-4' , H-5'). ${ }^{13} \mathrm{C}$ NMR (75.5 MHz, CD 30 OD): $\delta=69.3$ (C-4), 66.7 (C-3), 58.6 (C-5a), 57.4 (C-6), 45.8 (dansyl), 43.7 (C-6' $), 42.3$ (C-5), 30.4, 30.1, 29.6, 27.1, 26.5 (C-1', C-2', C-3', C-4' , C-5'). MS (MALDI): Calcd for $\left[\mathrm{C}_{24} \mathrm{H}_{37} \mathrm{~N}_{3} \mathrm{O}_{5} \mathrm{SH}\right]^{+}: \mathrm{m} / z 480.2532[\mathrm{M}]^{+}$; Found [M] ${ }^{+} 480.2531$.

\section{(3aR,3bS,6aS,7S,7aR)-1-Benzyl-7-bromo-5,5-dimethylhexahydro-1H[1,3]dioxolo[4' $\left.4^{\prime}: 3,4\right]$ cyclopenta[1,2-c]isoxazole (25)}

To an ice-cooled solution of alcohol 23 (ref. [57], $292 \mathrm{mg}, 1.00 \mathrm{mmol}$ ) in dichloromethane (10 mL), pyridine $(0.324 \mathrm{~mL}, 4.01 \mathrm{mmol})$ and trifluoromethanesulfonyl anhydride $(0.219 \mathrm{~mL}, 1.30 \mathrm{mmol})$ were added and the reaction was allowed to reach ambient temp under stirring. After completed conversion of the starting material, the reaction mixture was diluted with dichloromethane and consecutively washed with aqueous $\mathrm{HCl}(6 \%)$ and saturated aqueous sodium bicarbonate. After drying $\left(\mathrm{Na}_{2} \mathrm{SO}_{4}\right)$, the filtrate was concentrated under reduced pressure. Resulting crude triflate $\mathbf{2 4}$ was dissolved in DMF (10 mL) and $\mathrm{NaBr}(516 \mathrm{mg}, 5.01 \mathrm{mmol})$ was added and the mixture was stirred at ambient temp for $12 \mathrm{~h}$. The reaction mixture was then concentrated under reduced pressure, the residue was treated with $\mathrm{CH}_{2} \mathrm{Cl}_{2}$ and the resulting suspension was washed with brine. The organic layer 
was dried $\left(\mathrm{Na}_{2} \mathrm{SO}_{4}\right)$, filtered and solvents were removed. Purification of the remaining residue on silica gel (cyclohexane-EtOAc 10:1) provided bromodeoxy compound 25 (187 mg, $0.528 \mathrm{mmol}, 53 \%$, over 2 steps $)$ as a colorless syrup. $[\alpha]_{\mathrm{D}}^{20}:+11.8\left(c\right.$ 1.0, $\left.\mathrm{CHCl}_{3}\right) ;{ }^{1} \mathrm{H} \mathrm{NMR}\left(500 \mathrm{MHz}, \mathrm{CDCl}_{3}\right)$; Mixture of conformers: $\delta=4.71-4.54(\mathrm{~m}, 2 \mathrm{H}, \mathrm{H}-3, \mathrm{H}-4), 4.30\left(\mathrm{~m}, 1 \mathrm{H}, J_{5,6 \mathrm{a}} 4.2 \mathrm{~Hz}, J_{5,6 \mathrm{a}} 8.5 \mathrm{~Hz}, \mathrm{H}-6 \mathrm{a}\right), 4.08-4.01$ (m, 2 H, H-6b, N-Cㅂ-Ph), 3.98 (dd, 1 H, $\left.J_{1,2}=J_{2,3} 7.0 \mathrm{~Hz}, \mathrm{H}-2\right), 3.91-3.75$ (m, $2 \mathrm{H}, \mathrm{H}-1, \mathrm{~N}-\mathrm{C} \underline{\mathrm{H}}-\mathrm{Ph}$ ), 3.38-3.28 (m, $1 \mathrm{H}, \mathrm{H}-5), 1.54,1.32\left(2 \mathrm{~s}, 3 \mathrm{H}\right.$ each, $\left.\mathrm{C}\left(\mathrm{CH}_{3}\right)_{2}\right) .{ }^{13} \mathrm{C}$ NMR $\left(125.9 \mathrm{MHz}, \mathrm{CDCl}_{3}\right): \delta=113.5$, $113.4\left(\underline{\mathrm{C}}\left(\mathrm{CH}_{3}\right)_{2}\right), 88.7,88.2$ (C-3), 79.4, 78.9 (C-1), 78.5, 78.1 (C-4), 65.0 (C-6), 59.8, $59.7\left(\mathrm{~N}_{-} \mathrm{CH}_{2}-\mathrm{Ph}\right)$, 54.8 (C-2), 47.4, 47.1 (C-5), 27.5, 27.4, 25.6, $\left.25.6\left(\mathrm{C}_{\left(\mathrm{CH}_{3}\right.}\right)_{2}\right)$. MS (MALDI): Calcd for $\left[\mathrm{C}_{16} \mathrm{H}_{20} \mathrm{BrNO}_{3} \mathrm{H}\right]$ : $\mathrm{m} / \mathrm{z} 357.0705[\mathrm{M}]^{+}$; Found $[\mathrm{M}]^{+} 357.0708$.

\section{[(3aS,4R,5S,6aR)-5-Amino-2,3-dimethyltetrahydro-4H-cyclopenta[ $d][1,3]$ dioxol-4-yl]methanol (26)}

A $10 \%$ methanolic solution of bromo compound $25(187 \mathrm{mg}, 0.528 \mathrm{mmol})$ was stirred with Raney-Ni under an atmosphere of $\mathrm{H}_{2}$ at ambient pressure for $12 \mathrm{~h}$. After completed conversion of the starting material, the catalyst was removed by filtration, the filtrate was concentrated under reduced pressure and the remaining residue was chromatographically purified $\left(\mathrm{CHCl}_{3}-\mathrm{MeOH} 8: 1+1 \mathrm{vol} \%\right.$ aq. $\left.\mathrm{NH}_{4} \mathrm{OH}(25 \%)\right)$ to provide aminocyclopentane $26(65.4 \mathrm{mg}, 0.349 \mathrm{mmol}, 66 \%)$ as a pale yellow syrup. $[\alpha]_{\mathrm{D}}^{20}:-3.2(c=1.0, \mathrm{MeOH}) ;{ }^{1} \mathrm{H}$ NMR $\left(500 \mathrm{MHz}, \mathrm{CD}_{3} \mathrm{OD}\right) \delta=4.80\left(\mathrm{dd}, 1 \mathrm{H}, J_{2,3}=J_{3,4} 5.8 \mathrm{~Hz}, \mathrm{H}-3\right)$, 4.73 (dd, 1 H, J4,5 5.7 Hz, H-4), 3.98 (dd, 1 H, J5,6a 7.0 Hz, J6a,6b 11.1 Hz, H-6a), 3.94 (dd, 1 H, J5,6b 8.1 Hz, H-6b), 3.39 (m, 1 H, H-1), 2.10-2.02 (m, 2 H, H-2a, H-5), 2.01 (ddd, 1 H, $J_{2 b, 3} 5.8$ Hz, Ja, 2b $11.8 \mathrm{~Hz}$, $\mathrm{H}-2 \mathrm{~b}), 1.52,1.37\left(\mathrm{C}\left(\mathrm{CH}_{3}\right)_{2} .{ }^{13} \mathrm{C} \mathrm{NMR}\left(125.9 \mathrm{MHz}, \mathrm{CD}_{3} \mathrm{OD}\right) \delta=110.8\left(\underline{\mathrm{C}}\left(\mathrm{CH}_{3}\right)_{2}\right), 82.4(\mathrm{C}-3), 82.3(\mathrm{C}-4)\right.$, 59.0 (C-6), 56.0 (C-1), 51.2 (C-5), 40.7 (C-2), 26.9, $23.0\left(\mathrm{C}\left(\underline{\mathrm{C}}_{3}\right)_{2}\right)$. MS (MALDI): Calcd for $\left[\mathrm{C}_{9} \mathrm{H}_{17} \mathrm{NO}_{3} \mathrm{H}\right]$ : $m / z 188.1287[\mathrm{M}+\mathrm{H}]^{+}$; Found $[\mathrm{M}+\mathrm{H}]^{+} 188.1287$.

\section{$(1 R, 2 S, 3 R, 4 S)$-4-Amino-3-(hydroxymethyl)cyclopentane-1,2-diol (27)}

A solution of isopropylidene acetal $26(15.8 \mathrm{mg}, 84.4 \mu \mathrm{mol})$ in methanol $(0.5 \mathrm{~mL})$ was treated with aqueous $\mathrm{HCl}(2 \mathrm{M}, 0.5 \mathrm{~mL})$ at ambient temperature. After completed conversion was observed solvents were removed under reduced pressure and the remaining residue was purified on silica gel $\left(\mathrm{CHCl}_{3}-\mathrm{MeOH}-\mathrm{NH}_{4} \mathrm{OH}(25 \%) .8: 4: 1\right)$ to give free polyol 27 as the free base (10.2 $\left.\mathrm{mg}, 69.3 \mathrm{mmol}, 82 \%\right)$. $[\alpha]_{\mathrm{D}}^{20}:+18.5\left(c 0.86, \mathrm{H}_{2} \mathrm{O}, \mathrm{pH} 1\right) ;{ }^{1} \mathrm{H}$ NMR $\left(500 \mathrm{MHz}, \mathrm{CD}_{3} \mathrm{OD}\right) \delta=4.15\left(\mathrm{dd}, 1 \mathrm{H}, J_{2 \mathrm{~b}, 3} 4.4 \mathrm{~Hz}, J_{3,4} 3.9 \mathrm{~Hz}\right.$, $\left.J_{2 \mathrm{a}, 3} 8.4 \mathrm{~Hz}, \mathrm{H}-3\right), 4.08\left(\mathrm{dd}, 1 \mathrm{H}, J_{4,5} 3.8 \mathrm{~Hz}, \mathrm{H}-4\right), 3.93\left(\mathrm{dd}, 1 \mathrm{H}, J_{5,6 \mathrm{a}} 7.3 \mathrm{~Hz}, J_{6 \mathrm{a}, 6 \mathrm{~b}} 11.2 \mathrm{~Hz}, \mathrm{H}-6 \mathrm{a}\right), 3.83$ (dd, $1 \mathrm{H}, J_{5,6 \mathrm{~b}} 7.8 \mathrm{~Hz}, \mathrm{H}-6 \mathrm{~b}$ ), 3.61 (ddd, $\left.1 \mathrm{H}, J_{1,2 \mathrm{a}} 8 \mathrm{~Hz}, J_{1,2 \mathrm{~b}} 4.4 \mathrm{~Hz}, J_{1,5} 4 \mathrm{~Hz}, \mathrm{H}-1\right), 2.59$ (ddd, $1 \mathrm{H}, J_{2 \mathrm{a}, 3} 8.3 \mathrm{~Hz}$, $\left.J_{2 \mathrm{a}, 2 \mathrm{~b}} 14.3 \mathrm{~Hz}, J_{1,2 \mathrm{a}} 8 \mathrm{~Hz}, \mathrm{H}-2 \mathrm{a}\right), 2.20$ (dddd, $\left.1 \mathrm{H}, \mathrm{H}-5\right), 1.58$ (ddd, $1 \mathrm{H}, J_{1,2 \mathrm{~b}} 4.4 \mathrm{~Hz}, J_{2 \mathrm{~b}, 3} 8 \mathrm{~Hz}, \mathrm{H}-2 \mathrm{~b}$ ). ${ }^{13} \mathrm{C}$ NMR (125.9 MHz, CD $\left.{ }_{3} \mathrm{OD}\right) \delta=73.1$ (C-4), 72.1 (C-3), 57.2 (C-6), 50.1 (C-1), 45.3 (C-5), 37.3 (C-2). MS (MALDI): Calcd for $\left[\mathrm{C}_{9} \mathrm{H}_{17} \mathrm{NO}_{3} \mathrm{H}\right]: \mathrm{m} / z 148.0974[\mathrm{M}+\mathrm{H}]^{+}$; Found $[\mathrm{M}+\mathrm{H}]^{+} 148.0976$.

\section{6-[(3aS,4R,5S,6aR)-4-Hydroxymethyl-2,2-dimethyltetrahydro-4H-cyclopenta[d][1,3]dioxol-5-yl) amino]hexanoic nitrile (28)}

Intermediate 26 (25.4 mg, $0.136 \mathrm{mmol})$ was dissolved in DMF $(1 \mathrm{~mL})$, 6-bromohexanoic nitrile $(23.4 \mu \mathrm{L}, 0.176 \mathrm{mmol})$ and $\mathrm{NaHCO}_{3}(45.6 \mathrm{mg}, 0.705 \mathrm{mmol})$ were added and the mixture was stirred at $60{ }^{\circ} \mathrm{C}$ until quantitative conversion of the starting material was observed. The solvent was removed under reduced pressure and the remaining residue was purified by chromatography on silica gel $\left(\mathrm{CHCl}_{3}-\mathrm{MeOH} 15: 1+1 \mathrm{vol} \% \mathrm{NH}_{4} \mathrm{OH}(25 \%)\right)$ to yield cyanopentylamine $28(23.6 \mathrm{mg}, 62 \%)$ as a faintly yellow syrup. $[\alpha]_{\mathrm{D}}^{20}:+18.1\left(c 1.0, \mathrm{CHCl}_{3}\right) ;{ }^{1} \mathrm{H}-\mathrm{NMR}\left(300 \mathrm{MHz}, \mathrm{CDCl}_{3}\right): \delta=4.68\left(\mathrm{dd}, 1 \mathrm{H}, J_{2,3}=J_{3,4}\right.$ $6 \mathrm{~Hz}, \mathrm{H}-3), 4.57$ (dd, 1 H, J4,5 6 Hz, H-4), 4.05 (dd, 1 H, $\left.J_{5,6 \mathrm{a}} 7.7 \mathrm{~Hz}, J_{6 \mathrm{a}, 6 \mathrm{~b}} 11.7 \mathrm{~Hz}, \mathrm{H}-6 \mathrm{a}\right), 3.93$ (dd, $1 \mathrm{H}$, $\left.J_{5,6 \mathrm{~b}} 6.7 \mathrm{~Hz}, \mathrm{H}-6 \mathrm{~b}\right), 3.21$ (dd, $\left.1 \mathrm{H}, J_{1,2 \mathrm{~b}}=J_{1,5} 5.9 \mathrm{~Hz}, \mathrm{H}-1\right), 2.85-2.70\left(\mathrm{~m}, 2 \mathrm{H}, \mathrm{H}-1^{\prime} \mathrm{a}, \mathrm{NH}\right), 2.43-2.26$ (m, $\left.3 \mathrm{H}, \mathrm{H}-1^{\prime} \mathrm{b}, \mathrm{H}-5^{\prime}\right), 2.23-2.01$ (m, $\left.2 \mathrm{H}, \mathrm{H}-2 \mathrm{a}, \mathrm{H}-5\right), 1.73-1.38$ (m, 8 H, H-2b, H-2' , H-3' , H-4' , 6-O$1.28\left(2 \mathrm{~s}, 3 \mathrm{H}\right.$ each, $\left.\mathrm{C}\left(\mathrm{C}_{3}\right)_{2}\right) .{ }^{13} \mathrm{C}-\mathrm{NMR}\left(75.5 \mathrm{MHz}, \mathrm{CDCl}_{3}\right): \delta=119.7(\mathrm{CN}), 110.1\left(\underline{\mathrm{C}}\left(\mathrm{CH}_{3}\right)_{2}\right), 81.2,81.1$ (C-3, C-4), 61.3 (C-1), 59.7 (C-6), 47.8 (C-5), 47.4 (C-1'), 34.8 (C-2), 29.6, 26.8, 26.6, 25.4, 23,2, 17.2 (C-2', $\left.\mathrm{C}-3^{\prime}, \mathrm{C}-4^{\prime}, \mathrm{C}-5^{\prime}, \mathrm{C}\left(\mathrm{CH}_{3}\right)_{2}\right)$. MS (MALDI): Calcd for $\left[\mathrm{C}_{15} \mathrm{H}_{26} \mathrm{~N}_{2} \mathrm{O}_{3} \mathrm{H}\right]: \mathrm{m} / z 283.2022[\mathrm{M}+\mathrm{H}]^{+} ;$Found [M $+\mathrm{H}]^{+} 283.2020$. 


\section{(3aS,4R,5S,6aR)-5-(6-aminohexyl)amino-2,2-dimethyltetrahydro-4H-cyclopenta[ $d][1,3]$} dioxol-4-yl]methanol (29)

A 10\% methanolic solution of nitrile 28 was stirred with Raney-Ni under an atmosphere of $\mathrm{H}_{2}$ at ambient pressure and temperature until completed consumption of the starting material ( $30 \mathrm{~min})$. The catalyst was then removed by filtration, the filtrate was concentrated under reduced pressure and the remaining residue was chromatographed on silica gel $\left(\mathrm{CHCl}_{3}-\mathrm{MeOH}-\mathrm{NH}_{4} \mathrm{OH}(25 \%)\right.$ 8:4:1) providing diamine $29(18.5 \mathrm{mg}, 78 \%)$ as a pale yellow syrup. $[\alpha]_{\mathrm{D}}^{20}:-3.4(c 0.82, \mathrm{MeOH}) ;{ }^{1} \mathrm{H}-\mathrm{NMR}$ $\left(300 \mathrm{MHz}, \mathrm{CDCl}_{3}\right): \delta=4.68\left(\mathrm{dd}, 1 \mathrm{H}, J_{2,3}=J_{3,4} 6.0 \mathrm{~Hz}, \mathrm{H}-3\right), 4.57\left(\mathrm{dd}, 1 \mathrm{H}, J_{4,5} 5.8 \mathrm{~Hz}, \mathrm{H}-4\right), 4.05(\mathrm{dd}, 1 \mathrm{H}$, $\left.J_{5,6 \mathrm{a}} 7.6 \mathrm{~Hz}, J_{6 \mathrm{a}, 6 \mathrm{~b}} 11.6 \mathrm{~Hz}, \mathrm{H}-6 \mathrm{a}\right), 3.93\left(\mathrm{dd}, 1 \mathrm{H}, J_{5,6 \mathrm{~b}} 6.4 \mathrm{~Hz}, \mathrm{H}-6 \mathrm{~b}\right), 3.22\left(\mathrm{dd}, 1 \mathrm{H}, J_{1,2 \mathrm{~b}}=J_{1,5} 6.0 \mathrm{~Hz}, \mathrm{H}-1\right)$, 3.10 (bs, $\left.3 \mathrm{H}, 1-\mathrm{NH}, 6^{\prime}-\mathrm{NH}_{2}\right), 2.72$ (m, 3 H, H-1'a, H-6'), 2.37 (m, 1 H, H-1' b) , 2.22-2.01 (m, 2 H, H-2a, $\mathrm{H}-5), 1.67-1.54$ (m, $1 \mathrm{H}, \mathrm{H}-2 \mathrm{~b}), 1.53-1.22$ (m, $\left.15 \mathrm{H}, \mathrm{H}-2^{\prime}, \mathrm{H}-3^{\prime}, \mathrm{H}-4^{\prime}, \mathrm{H}-5^{\prime}, 6-\mathrm{O} \underline{\mathrm{H}}, \mathrm{C}\left(\mathrm{C}_{3}\right)_{2}\right) .{ }^{13} \mathrm{C}-\mathrm{NMR}$ $\left(75.5 \mathrm{MHz}, \mathrm{CDCl}_{3}\right): \delta=110.1\left(\underline{\mathrm{C}}\left(\mathrm{CH}_{3}\right)_{2}\right), 81.3,81.0(\mathrm{C}-3, \mathrm{C}-4), 61.3(\mathrm{C}-1), 59.6(\mathrm{C}-6), 47.7,47.6\left(\mathrm{C}-5, \mathrm{C}-1^{\prime}\right)$, 41.8 (C-6'), 34.9 (C-2), 32.6, 30.2, 27.2, 26.7, 26.7, 23.2 (C-2', C-3', C-4' $\left.{ }^{\prime} \mathrm{C}-5^{\prime}, \mathrm{C}\left(\mathrm{C}_{3}\right)_{2}\right)$. MS (MALDI): Calcd for $\left[\mathrm{C}_{15} \mathrm{H}_{30} \mathrm{~N}_{2} \mathrm{O}_{3} \mathrm{H}\right]: \mathrm{m} / z 287.2335[\mathrm{M}+\mathrm{H}]^{+}$; Found $[\mathrm{M}+\mathrm{H}]^{+}$287.2332.

\section{(3aS,4R,5S,6aR)-2,2-Dimethyl-5-[6-(dansylamino)hexyl]aminotetrahydro-4H-cyclopenta[ $d][1,3]$} dioxol-4-yl)methanol (30)

A solution of diamine $29(18.2 \mathrm{mg}, 63.5 \mu \mathrm{mol})$ in $\mathrm{CH}_{2} \mathrm{Cl}_{2}-\mathrm{DMF}(1 \mathrm{~mL}, 3: 1)$ was treated with trimethylamine $(35.4 \mu \mathrm{L}, 254 \mu \mathrm{mol})$ and dansyl chloride $(18.9 \mathrm{mg}, 69.9 \mu \mathrm{mol})$. After completed conversion of the starting material $(20 \mathrm{~min})$, the solvents were removed under reduced pressure and the residue was chromatographed on silica gel $\left(\mathrm{CHCl}_{3}-\mathrm{MeOH} 15: 1+1 \mathrm{vol} \% \mathrm{NH}_{4} \mathrm{OH}(25 \%)\right)$ furnishing dansyl amide $30(27.6 \mathrm{mg}, 48.6 \mu \mathrm{mol}, 84 \%)$ as a yellow syrup. $[\alpha]_{\mathrm{D}}^{20}:-1.4(c 1.1, \mathrm{MeOH}) ;{ }^{1} \mathrm{H}-\mathrm{NMR}$ $\left(300 \mathrm{MHz}, \mathrm{CDCl}_{3}\right): \delta=4.98$ (bs, $1 \mathrm{H}, \mathrm{N} \underline{\mathrm{H}}$-dansyl), 4.67 (dd, $\left.1 \mathrm{H}, J_{2 \mathrm{~b}, 3}=J_{3,4} 6.0 \mathrm{~Hz}, \mathrm{H}-3\right), 4.56(\mathrm{dd}, 1 \mathrm{H}$, $\left.J_{4,5} 5.8 \mathrm{~Hz}, \mathrm{H}-4\right), 4.05\left(\mathrm{dd}, 1 \mathrm{H}, J_{5,6 \mathrm{a}} 7.6 \mathrm{~Hz}, J_{6 \mathrm{a}, 6 \mathrm{~b}} 11.4 \mathrm{~Hz}, \mathrm{H}-6 \mathrm{a}\right), 3.94\left(\mathrm{dd}, 1 \mathrm{H}, J_{5,6 \mathrm{~b}} 6.5 \mathrm{~Hz}, \mathrm{H}-6 \mathrm{~b}\right), 3.19$ (m, $\left.1 \mathrm{H}, J_{1,2 \mathrm{~b}}=J_{1,5} 5.8 \mathrm{~Hz}, \mathrm{H}-1\right), 2.91-2.82\left(\mathrm{~m}, 8 \mathrm{H}, \mathrm{H}-6^{\prime}\right.$, dansyl), 2.70-2.59 (m, $\left.1 \mathrm{H}, \mathrm{H}-1^{\prime} \mathrm{a}\right), 2.34-2.23$ (m, $\left.1 \mathrm{H}, \mathrm{H}-1^{\prime} \mathrm{b}\right), 2.19-1.98$ (m, $\left.2 \mathrm{H}, \mathrm{H}-2 \mathrm{a}, \mathrm{H}-5\right), 1.60$ (ddd, $\left.1 \mathrm{H}, J_{1,2 \mathrm{~b}} 14.9 \mathrm{~Hz}, \mathrm{H}-2 \mathrm{~b}\right), 1.43,1.27$ (2 s, 3H each, $\left.\mathrm{C}\left(\mathrm{C}_{3}\right)_{2}\right), 1.41-1.06\left(\mathrm{~m}, 5 \mathrm{H}, \mathrm{H}-2^{\prime}, \mathrm{H}-3^{\prime}, \mathrm{H}-4^{\prime}, \mathrm{H}-5^{\prime}\right) .{ }^{13} \mathrm{C}-\mathrm{NMR}\left(75.5 \mathrm{MHz}, \mathrm{CDCl}_{3}\right): \delta=110.1\left(\underline{\mathrm{C}}\left(\mathrm{CH}_{3}\right)_{2}\right)$, 81.2, 81.0 (C-4, C-3), 61.4 (C-1), 59.7 (C-6), 47.5, 47.4 (C-5, C-1'), 45.5 (dansyl), 43.2 (C-6'), 34.9 (C-2), 29.8, 29.6, 26.7, 26.6, 26.1, $23.2\left(\mathrm{C}-2^{\prime}, \mathrm{C}-3^{\prime}, \mathrm{C}-4^{\prime}, \mathrm{C}-5^{\prime}, \mathrm{C}\left(\mathrm{CH}_{3}\right)_{2}\right)$. MS (MALDI): Calcd for $\left[\mathrm{C}_{27} \mathrm{H}_{41} \mathrm{~N}_{3} \mathrm{O}{ }_{5} \mathrm{SH}\right]$ : $m / z 520.2845[\mathrm{M}+\mathrm{H}]^{+} ;$Found $[\mathrm{M}+\mathrm{H}]^{+} 520.2848$.

\section{(1R,2S,3R,4S)-3-Hydroxymethyl-4-(6'-dansylaminohexylamino)cyclopentane-1,2-diol (31)}

A solution of isopropylidene acetal $30(27.4 \mathrm{mg}, 527 \mu \mathrm{mol})$ in THF $(0.5 \mathrm{~mL})$ was treated with aqueous $\mathrm{HCl}(1 \mathrm{M}, 0.5 \mathrm{~mL})$ at ambient temperature. Solvents were removed under reduced pressure and the remaining residue was purified on silica gel $\left(\mathrm{CHCl}_{3}-\mathrm{MeOH} 8: 1+1 \mathrm{vol} \% \mathrm{NH}_{4} \mathrm{OH}(25 \%)\right)$ to give free carbasugar 31 as the free base $(18.5 \mathrm{mg}, 38.6 \mu \mathrm{mol}, 73 \%)$. $[\alpha]_{\mathrm{D}}^{20}:+17.6(c 0.80, \mathrm{MeOH}$, free base); ${ }^{1} \mathrm{H}-\mathrm{NMR}\left(300 \mathrm{MHz}, \mathrm{CDCl}_{3}\right): \delta=4.04\left(\mathrm{ddd}, 1 \mathrm{H}, J_{2 \mathrm{a}, 3} 7.9 \mathrm{~Hz}, J_{2 \mathrm{~b}, 3}=J_{3,4} 4.3 \mathrm{~Hz}, \mathrm{H}-3\right), 3.96(\mathrm{dd}, 1 \mathrm{H}$, $\left.J_{4,5} 4.4 \mathrm{~Hz}, \mathrm{H}-4\right), 3.93-3.86$ (m, 2 H, H-6a, H-6b), 3.39 (ddd, 1 H, J,2b $=J_{1,5} 5.4 \mathrm{~Hz}, \mathrm{H}-1$ ), 2.93-2.80 (m, $8 \mathrm{H}, \mathrm{H}-6^{\prime}$, dansyl), 2.79-2.54 (m, $\left.2 \mathrm{H}, \mathrm{H}-1^{\prime}\right), 2.37$ (ddd, $\left.1 \mathrm{H}, J_{1,2 \mathrm{a}}=J_{2 \mathrm{a}, 3} 7.9 \mathrm{~Hz}, J_{2 \mathrm{a}, 2 \mathrm{~b}} 14.2 \mathrm{~Hz}, \mathrm{H}-2 \mathrm{a}\right)$, 2.23 (dddd, 1 H, J5,6a $=J_{5,6 b} 7$ Hz, H-5), 1.69 (m, 1 H, H-2b), 1.49-1.04 (m, 8 H, H-2' , H-3', H-4' , H-5' $)$. ${ }^{13} \mathrm{C}-\mathrm{NMR}(75.5 \mathrm{MHz}, \mathrm{CDCl} 3)$ : $\delta=74.5$ (C-4), $73.2(\mathrm{C}-3), 58.8(\mathrm{C}-6), 58.6(\mathrm{C}-1), 48.4\left(\mathrm{C}-1^{\prime}\right), 47.0(\mathrm{C}-5)$, 45.8 (dansyl), 43.7 (C-6'), 37.4 (C-2), 30.4, 28.4, 27.3, 27.1 (C-2' , C-3', C-4' , C-5'). MS (MALDI): Calcd for $\left[\mathrm{C}_{24} \mathrm{H}_{37} \mathrm{~N}_{3} \mathrm{O}_{5} \mathrm{SH}\right]: m / z 480.2532[\mathrm{M}+\mathrm{H}]^{+}$; Found $[\mathrm{M}+\mathrm{H}]^{+} 480.2533$.

\section{(3aR,3bS,6aS,7S,7aR)-1-Benzyl-7-fluoro-5,5-dimethylhexahydro-1 $H$-[1,3]dioxolo[ $\left.4^{\prime}, 5^{\prime}: 3,4\right]$ cyclopenta[1,2-c]isoxazole (32)}

A solution of alcohol 23 (ref. [57], $298 \mathrm{mg}, 1.02 \mathrm{mmol})$ in $\mathrm{CH}_{2} \mathrm{Cl}_{2}(10 \mathrm{~mL})$ was cooled to $0{ }^{\circ} \mathrm{C}$ and treated with pyridine $(0.330 \mathrm{~mL}, 4.09 \mathrm{mmol})$ and DAST $(0.270 \mathrm{~mL}, 2.05 \mathrm{mmol})$. When completed conversion of the starting material was observed $(2 \mathrm{~h})$, the reaction mixture was quenched with 
saturated aqueous $\mathrm{NaHCO}_{3}$ and the organic layer was dried with $\mathrm{Na}_{2} \mathrm{SO}_{4}$, filtered and the solvent was removed under reduced pressure. Purification of the residue on silica gel (cyclohexane-EtOAc 10:1) provided deoxyfluoro compound $32(245 \mathrm{mg}, 0.835 \mathrm{mmol}, 82 \%)$. $[\alpha]_{\mathrm{D}}^{20}:+55.5\left(\mathrm{c} 1.6, \mathrm{CHCl}_{3}\right) ;{ }^{1} \mathrm{H} \mathrm{NMR}$ $\left(500 \mathrm{MHz}, \mathrm{CDCl}_{3}\right): \delta=4.78\left(\mathrm{~m}, 1 \mathrm{H}, J_{2, \mathrm{~F}} 50.7 \mathrm{~Hz}, \mathrm{H}-2\right), 4.60(\mathrm{~m}, 1 \mathrm{H}, \mathrm{H}-4), 4.58\left(\mathrm{~m}, 1 \mathrm{H}, J_{3, \mathrm{~F}} 19 \mathrm{~Hz}, J_{2,3}\right.$ $\left.6.5 \mathrm{~Hz}, J_{3,4} 3.7 \mathrm{~Hz}, \mathrm{H}-3\right), 4.20$ (dd, $\left.1 \mathrm{H}, J_{5,6 \mathrm{a}} 3.7 \mathrm{~Hz}, J_{6 \mathrm{a}, 6 \mathrm{~b}} 8.6 \mathrm{~Hz}, \mathrm{H}-6 \mathrm{a}\right), 3.98-3.89$ (m, 2 H, J5,6b $8.5 \mathrm{~Hz}$,

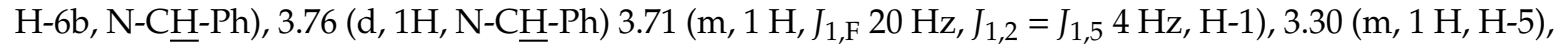
1.46, $1.24\left(2 \mathrm{~s}, 3 \mathrm{H}\right.$ each, $\left.\mathrm{C}\left(\mathrm{C}_{3}\right)_{2}\right) .{ }^{13} \mathrm{C}$ NMR $\left(75.5 \mathrm{MHz}, \mathrm{CDCl}_{3}\right): \delta=113.0\left(\underline{\mathrm{C}}\left(\mathrm{CH}_{3}\right)_{2}\right), 100.3\left(\mathrm{~J}_{2, \mathrm{~F}} 182 \mathrm{~Hz}\right.$, C-2), $85.3\left(J_{2, \mathrm{~F}} 27.9 \mathrm{~Hz}, \mathrm{C}-3\right), 77.7\left(\mathrm{~J}_{4, \mathrm{~F}} 4.7 \mathrm{~Hz}, \mathrm{C}-4\right), 75.9\left(\mathrm{~J}_{1, \mathrm{~F}} 25.1 \mathrm{~Hz}, \mathrm{C}-1\right), 65.0(\mathrm{C}-6), 59.8\left(\mathrm{~N}_{-} \mathrm{CH}_{2}-\mathrm{Ph}\right)$, 47.5, $\left(J_{5, \mathrm{~F}} 3.5 \mathrm{~Hz}, \mathrm{C}-5\right), 26.9,25.3\left(\mathrm{C}_{\left.\left(\mathrm{CH}_{3}\right)_{2}\right) .}{ }^{19} \mathrm{~F}\right.$ NMR $\left(470.3 \mathrm{MHz}, \mathrm{CDCl}_{3}\right): \delta=-189.4$. MS (MALDI): Calcd for $\left[\mathrm{C}_{16} \mathrm{H}_{20} \mathrm{FNO}_{3} \mathrm{H}\right]: \mathrm{m} / z 294.1505[\mathrm{M}+\mathrm{H}]^{+}$; Found $[\mathrm{M}+\mathrm{H}]^{+} 294.1504$.

\section{[(3aS,4R,5R,6S,6aS)-5-Amino-6-fluoro-2,2-dimethyltetrahydro-4H-cyclopenta[d][1,3]dioxol-4-yl] methanol (33)}

A methanolic solution ( $3 \%$ ) of isoxazolidine $32(348 \mathrm{mg}, 1.18 \mathrm{mmol})$ was stirred with Pearlman's catalyst $\left(\mathrm{Pd}(\mathrm{OH})_{2} / \mathrm{C}, 20 \%\right)$ under an atmosphere of $\mathrm{H}_{2}$ at ambient pressure for $1 \mathrm{~h}$. After completed conversion, the suspension was filtered, the filtrate was concentrated under reduced pressure and the residue was chromatographically purified $\left(\mathrm{CHCl}_{3}-\mathrm{MeOH} 14: 1+1 \mathrm{vol} \% \mathrm{NH}_{4} \mathrm{OH}(25 \%)\right)$ to obtain 33 as a pale yellow syrup (238 mg, $1.16 \mathrm{mmol}, 98 \%)$. $[\alpha]_{\mathrm{D}}^{20}:+22.5\left(\right.$ c $\left.0.70, \mathrm{CHCl}_{3}\right) ;{ }^{1} \mathrm{H} \mathrm{NMR}(500 \mathrm{MHz}$, $\left.\mathrm{CDCl}_{3}\right): \delta=4.73\left(\mathrm{dd}, 1 \mathrm{H}, J_{3,4}=J_{4,5} 5.4 \mathrm{~Hz}, \mathrm{H}-2\right), 4.72\left(\mathrm{bd}, 1 \mathrm{H}, J_{2, \mathrm{~F}} 48 \mathrm{~Hz}, \mathrm{H}-2\right), 4.60(\mathrm{ddd}, 1 \mathrm{H}$, $\left.J_{3, \mathrm{~F}} 16.6 \mathrm{~Hz}, J_{2,3} 5.8 \mathrm{~Hz}, \mathrm{H}-3\right), 4.01$ (dd, $\left.1 \mathrm{H}, J_{5,6 \mathrm{a}} 7.7 \mathrm{~Hz}, J_{6 \mathrm{a}, 6 \mathrm{~b}} 11.3 \mathrm{~Hz}, \mathrm{H}-6 \mathrm{a}\right), 3.95$ (dd, $1 \mathrm{H}, J_{5,6 \mathrm{~b}} 6.8 \mathrm{~Hz}$, H-6b), 3.47 (dd, 1 H, J1, $14.4 \mathrm{~Hz}, J_{1,5} 6.3 \mathrm{~Hz}, \mathrm{H}-1$ ), 2.44 (ddd, $\left.1 \mathrm{H}, \mathrm{H}-5\right), 2.07$ (bs, $3 \mathrm{H}, 6-\mathrm{OH}, 1-\mathrm{N}_{2}$ ), 1.45, $1.29\left(2 \mathrm{~s}, 3 \mathrm{H}\right.$ each, $\left.\mathrm{C}\left(\mathrm{C}_{3}\right)_{2}\right) .{ }^{13} \mathrm{C}$ NMR $\left(75.5 \mathrm{MHz}, \mathrm{CDCl}_{3}\right): \delta=111.3\left(\underline{\mathrm{C}}\left(\mathrm{CH}_{3}\right)_{2}\right), 100.5\left(J_{2, \mathrm{~F}}\right.$ $180.5 \mathrm{~Hz}, \mathrm{C}-2), 84.1\left(J_{3, \mathrm{~F}} 33.7 \mathrm{~Hz}, \mathrm{C}-3\right), 80.9$ (C-4), 58.1 (J,F $\left.22.4 \mathrm{~Hz}, \mathrm{C}-1\right), 58.0$ (C-6), 46.4, (C-5), 26.3, $25.0\left(\mathrm{C}\left(\mathrm{CH}_{3}\right)_{2}\right) .{ }^{19} \mathrm{~F}$ NMR $\left(470.3 \mathrm{MHz}, \mathrm{CDCl}_{3}\right): \delta=-181.1$. MS (MALDI): Calcd for $\left[\mathrm{C}_{9} \mathrm{H}_{16} \mathrm{NO}_{3} \mathrm{H}\right]$ : $m / z 206.1192[\mathrm{M}+\mathrm{H}]^{+} ;$Found $[\mathrm{M}+\mathrm{H}]^{+} 206.1192$.

\section{(1S,2S,3S,4R,5R)-4-Amino-3-fluoro-5-hydroxymethylcyclopentane-1,2-diol (34)}

A $10 \%$ methanolic solution of compound $33(238 \mathrm{mg}, 1.16 \mathrm{mmol})$ was treated with $\mathrm{HCl}(12 \mathrm{M}$, $0.1 \mathrm{~mL}$ ) for $2 \mathrm{~h}$. After completed conversion of the starting material, the solution was concentrated under reduced pressure and the residue was chromatographically purified $\left(\mathrm{CHCl}_{3}-\mathrm{MeOH}-\mathrm{NH}_{4} \mathrm{OH}\right.$ (25\%) 8:4:1) to obtain free compound 34 (177 $\mathrm{mg}, 1.07 \mathrm{mmol}, 92 \%)$ as a colorless syrup. Treatment with $\mathrm{HCl}_{\mathrm{g}}$ in methanol in the presence of small amounts of ethyl acetate afforded the corresponding hydrochloride $\left(34 \cdot \mathrm{HCl}\right.$ ) as a white solid. $[\alpha]_{\mathrm{D}}^{20}:+31.2$ (free base, $\left.c 0.88, \mathrm{H}_{2} \mathrm{O}\right) ;{ }^{1} \mathrm{H}$ NMR $\left(500 \mathrm{MHz}, \mathrm{D}_{2} \mathrm{O}\right.$ ) (free base): $\delta=5.17$ (ddd, $\left.1 \mathrm{H}, J_{2, \mathrm{~F}} 52.5 \mathrm{~Hz}, J_{1,2} 3.9 \mathrm{~Hz}, J_{2,3} 7.0 \mathrm{~Hz}, \mathrm{H}-2\right), 4.32\left(\mathrm{dd}, 1 \mathrm{H}, J_{3, \mathrm{~F}}=21.7 \mathrm{~Hz}\right.$, $\left.J_{3,4} 3.9 \mathrm{~Hz}, \mathrm{H}-3\right), 4.27$ (dd, $\left.1 \mathrm{H}, J_{4,5} 4 \mathrm{~Hz}, \mathrm{H}-4\right), 4.01$ (ddd, 1 H, $\left.J_{1, \mathrm{~F}} 20.8 \mathrm{~Hz}, J_{1,5} 8.8 \mathrm{~Hz}, \mathrm{H}-1\right), 3.99$ (dd, $\left.1 \mathrm{H}, J_{5,6 \mathrm{a}} 6.6 \mathrm{~Hz}, J_{6 \mathrm{a}, 6 \mathrm{~b}} 11.7 \mathrm{~Hz}, \mathrm{H}-6 \mathrm{a}\right), 3.91$ (dd, $\left.1 \mathrm{H}, J_{5,6 \mathrm{~b}} 8.0 \mathrm{~Hz}, \mathrm{H}-6 \mathrm{~b}\right), 2.79$ (dddd, $\left.1 \mathrm{H}, \mathrm{H}-5\right) .{ }^{13} \mathrm{C}$ NMR (75.5 MHz, $\left.\mathrm{D}_{2} \mathrm{O}\right)$ (free base): $\delta=101.6\left(J_{2, \mathrm{~F}} 185.9 \mathrm{~Hz}, \mathrm{C}-2\right), 76.1\left(J_{3, \mathrm{~F}} 22.0 \mathrm{~Hz}, \mathrm{C}-3\right), 72.2\left(J_{4, \mathrm{~F}} 9.1 \mathrm{~Hz}\right.$, C-4), $56.6(\mathrm{C}-6), 54.4\left(J_{1, \mathrm{~F}} 26.8 \mathrm{~Hz}, \mathrm{C}-1\right), 41.8,\left(J_{5, \mathrm{~F}} 2.7 \mathrm{~Hz}, \mathrm{C}-5\right) .{ }^{19} \mathrm{~F}$ NMR $\left(470.3 \mathrm{MHz}, \mathrm{D}_{2} \mathrm{O}\right)$ (free base): $\delta=-192.4 .{ }^{1} \mathrm{H}$ NMR $\left(300 \mathrm{MHz}, \mathrm{D}_{2} \mathrm{O}\right)$ (hydrochloride): $\delta=5.12\left(\mathrm{ddd}, 1 \mathrm{H}, J_{2, \mathrm{~F}} 52.3 \mathrm{~Hz}, J_{1,2} 3.9 \mathrm{~Hz}, J_{2,3}\right.$ $6.6 \mathrm{~Hz}, \mathrm{H}-2), 4.26\left(\mathrm{dd}, 1 \mathrm{H}, J_{3, \mathrm{~F}}=21.3 \mathrm{~Hz}, J_{3,4} 4.1 \mathrm{~Hz}, \mathrm{H}-3\right), 4.20\left(\mathrm{dd}, 1 \mathrm{H}, J_{4,5} 3.8 \mathrm{~Hz}, \mathrm{H}-4\right), 3.97(\mathrm{ddd}, 1 \mathrm{H}$, $\left.J_{1, \mathrm{~F}} 20.9 \mathrm{~Hz}, J_{1,5} 8.8 \mathrm{~Hz}, \mathrm{H}-1\right), 3.92\left(\mathrm{dd}, 1 \mathrm{H}, J_{5,6 \mathrm{a}} 6.9 \mathrm{~Hz}, J_{6 \mathrm{a}, 6 \mathrm{~b}} 11.5 \mathrm{~Hz}, \mathrm{H}-6 \mathrm{a}\right), 3.83$ (dd, $1 \mathrm{H}, J_{5,6 \mathrm{~b}} 8.2 \mathrm{~Hz}$, H-6b), 2.74 (dddd, $1 \mathrm{H}, \mathrm{H}-5) .{ }^{13} \mathrm{C}$ NMR $\left(75.5 \mathrm{MHz}, \mathrm{D}_{2} \mathrm{O}\right)$ (hydrochloride): $\delta=100.9\left(J_{2, \mathrm{~F}} 186.3 \mathrm{~Hz}, \mathrm{C}-2\right)$, $76.1\left(J_{3, \mathrm{~F}} 22.0 \mathrm{~Hz}, \mathrm{C}-3\right), 72.1\left(J_{4, \mathrm{~F}} 9.1 \mathrm{~Hz}, \mathrm{C}-4\right), 56.5(\mathrm{C}-6), 54.4\left(J_{1, \mathrm{~F}} 27.3 \mathrm{~Hz}, \mathrm{C}-1\right), 41.5,\left(J_{5, \mathrm{~F}} 2.5 \mathrm{~Hz}, \mathrm{C}-5\right)$. MS (MALDI): Calcd for $\left[\mathrm{C}_{6} \mathrm{H}_{12} \mathrm{FNO}_{3} \mathrm{H}\right]: \mathrm{m} / z 166.0880[\mathrm{M}+\mathrm{H}]^{+}$; Found $[\mathrm{M}+\mathrm{H}]^{+}$166.0883.

\section{Benzyl 6-(1R,2S,3S,4S,5R)-2-fluoro-3,4-dihydroxy-5-(hydroxymethyl)cyclopentylamino hexylcarbamate (35)}

To a $10 \%$ solution of amine $34(117 \mathrm{mg}, 0.708 \mathrm{mmol})$ and acetic acid $(40 \mu \mathrm{L})$, benzyl (6-oxohexyl) carbamate [68] (230 mg, $0.921 \mathrm{mmol})$ was added. After $5 \mathrm{~min}$, sodium cyanoborohydrate $(66.8 \mathrm{mg}$, 
$1.06 \mathrm{mmol}$ ) was added and the suspension was stirred until completed conversion was observed $(1 \mathrm{~h})$. The solvent was removed under reduced pressure and the residue was chromatographically purified $\left(\mathrm{CHCl}_{3}-\mathrm{MeOH} 8: 1+1 \mathrm{vol} \% \mathrm{NH}_{4} \mathrm{OH}(25 \%)\right)$ to obtain compound 35 as a colorless syrup (169 mg, $0.424 \mathrm{mmol}, 60 \%) .[\alpha]_{\mathrm{D}}^{20}:+16.8\left(c\right.$ 1.1, MeOH); ${ }^{1} \mathrm{H}$ NMR $\left(500 \mathrm{MHz}, \mathrm{CD}_{3} \mathrm{OD}\right): \delta=5.13(\mathrm{~s}, 2 \mathrm{H}$, $\left.\mathrm{NH}(\mathrm{C}-\mathrm{O})-\mathrm{O}-\mathrm{C}_{2}-\mathrm{Ph}\right), 4.85$ (ddd, $\left.1 \mathrm{H}, J_{2, \mathrm{~F}} 53.4 \mathrm{~Hz}, J_{1,2}=J_{2,3} 4.6 \mathrm{~Hz}, \mathrm{H}-2\right), 4.12$ (dd, $1 \mathrm{H}, J_{3,4}=J_{3,4} 4.4 \mathrm{~Hz}$, H-4), 4.05 (ddd, 1 H, J3,F $22.2 \mathrm{~Hz}, \mathrm{H}-3), 3.94$ (dd, 1 H, J5,6a 6.8 Hz, J6a,6b $11.4 \mathrm{~Hz}, \mathrm{H}-6 \mathrm{a}), 3.84$ (dd, $1 \mathrm{H}$, $\left.J_{5,6 \mathrm{~b}} 6.6 \mathrm{~Hz}, \mathrm{H}-6 \mathrm{~b}\right), 3.24\left(\mathrm{ddd}, 1 \mathrm{H}, J_{1, \mathrm{~F}} 21.8 \mathrm{~Hz}, J_{1,5} 8.4 \mathrm{~Hz}, \mathrm{H}-1\right), 3.18\left(\mathrm{t}, 2 \mathrm{H}, J 6.9 \mathrm{~Hz}, \mathrm{H}-6^{\prime}\right), 2.81(\mathrm{~m}, 1 \mathrm{H}$, H-1'a), 2.60 (m, 1 H, H-1' b), 2.46 (m, 1 H, H-5), 1.63-1.34 (m, 8 H, H-2' , H-3' , H-4' , H-5'). ${ }^{13} \mathrm{C} \mathrm{NMR}$ (75.5 MHz, CD ${ }_{3} \mathrm{OD}$ ) (free base): $\delta=158.9\left(\mathrm{NH}(\underline{\mathrm{C}}-\mathrm{O})-\mathrm{O}-\mathrm{CH}_{2}-\mathrm{Ph}\right), 106.0\left(J_{2, \mathrm{~F}} 185.0 \mathrm{~Hz}, \mathrm{C}-2\right), 78.5\left(J_{3, \mathrm{~F}}\right.$ $23.1 \mathrm{~Hz}, \mathrm{C}-3), 73.6\left(J_{4, \mathrm{~F}} 8.3 \mathrm{~Hz}, \mathrm{C}-4\right), 67.3\left(\mathrm{~N}(\mathrm{C}-\mathrm{O})-\mathrm{O}-\mathrm{CH}_{2}-\mathrm{Ph}\right), 63.2\left(J_{1, \mathrm{~F}} 22.4 \mathrm{~Hz}, \mathrm{C}-1\right), 58.7$ (C-6), 45.9 , $\left(J_{5, \mathrm{~F}} 3.8 \mathrm{~Hz}, \mathrm{C}-5\right), 41.7\left(\mathrm{C}-6^{\prime}\right), 30.8,30.5,28.0,27.6\left(\mathrm{C}-2^{\prime}, \mathrm{C}-3^{\prime}, \mathrm{C}-4^{\prime}, \mathrm{C}-5^{\prime}\right) .{ }^{19} \mathrm{~F}$ NMR $\left(470.3 \mathrm{MHz}, \mathrm{CD}_{3} \mathrm{OD}\right)$ : $\delta=-184.3$. MS (MALDI): Calcd for $\left[\mathrm{C}_{6} \mathrm{H}_{12} \mathrm{FNO}_{3} \mathrm{H}\right]: \mathrm{m} / z 399.2295[\mathrm{M}+\mathrm{H}]^{+}$; Found $[\mathrm{M}+\mathrm{H}]^{+}$399.2295.

\section{(1S,2S,3S,4R,5R)-4-(6'-Dansylaminohexyl)amino-3-fluoro-5-hydroxymethylcyclopentane-1,2- diol (37)}

To a solution of carbamate 35 (52.5 mg, $0.132 \mathrm{mmol}$ ) in $\mathrm{MeOH}, 10 \% \mathrm{Pd} / \mathrm{C}$ was added and the suspension was stirred under an atmosphere of $\mathrm{H}_{2}$ at ambient pressure. After completed conversion was observed $(1 \mathrm{~h})$, the suspension was filtered and the filtrate was concentrated under reduced pressure. The residue of crude free amine 36 was dissolved in $\mathrm{CH}_{3} \mathrm{CN} / \mathrm{H}_{2} \mathrm{O}(1 \mathrm{~mL}, 5: 1)$ and treated with $\mathrm{Et}_{3} \mathrm{~N}(55.1 \mu \mathrm{L}, 0.395 \mathrm{mmol})$ and dansyl chloride $(39.1 \mathrm{mg}, 0.145 \mathrm{mmol})$. After completed conversion of the starting material $(20 \mathrm{~min})$, the solvent was removed under reduced pressure. Purification on silica gel $\left(\mathrm{CHCl}_{3}-\mathrm{MeOH} .8: 1+1\right.$ vol\% $\mathrm{NH}_{4} \mathrm{OH}(25 \%)$ ) provided compound 37 (38.2 mg, $69.2 \mu \mathrm{mol}, 53 \%$, over 2 steps) as yellow syrup. $[\alpha]_{\mathrm{D}}^{20}:+14.0(c 1.8, \mathrm{MeOH}) ;{ }^{1} \mathrm{H}$ NMR $\left(500 \mathrm{MHz}, \mathrm{CD}_{3} \mathrm{OD}\right): \delta=4.83(\mathrm{ddd}$, $\left.1 \mathrm{H}, J_{2, \mathrm{~F}} 53.4 \mathrm{~Hz}, J_{1,2} 4.0 \mathrm{~Hz}, J_{2,3} 4.4 \mathrm{~Hz}, \mathrm{H}-2\right), 4.12\left(\mathrm{dd}, 1 \mathrm{H}, J_{3,4}=J_{3,4} 4.6 \mathrm{~Hz}, \mathrm{H}-4\right), 4.05\left(\mathrm{ddd}, 1 \mathrm{H}, J_{3, \mathrm{~F}}\right.$ $22.2 \mathrm{~Hz}, \mathrm{H}-3), 3.92\left(\mathrm{dd}, 1 \mathrm{H}, J_{5,6 \mathrm{a}} 6.8 \mathrm{~Hz}, J_{6 \mathrm{a}, 6 \mathrm{~b}} 11.2 \mathrm{~Hz}, \mathrm{H}-6 \mathrm{a}\right), 3.82\left(\mathrm{dd}, 1 \mathrm{H}, J_{5,6 \mathrm{~b}} 6.5 \mathrm{~Hz}, \mathrm{H}-6 \mathrm{~b}\right), 3.20$ (ddd, $\left.1 \mathrm{H}, J_{1, \mathrm{~F}} 21.7 \mathrm{~Hz}, J_{1,5} 8.3 \mathrm{~Hz}, \mathrm{H}-1\right), 2.96-2.88$ (m, $8 \mathrm{H}, \mathrm{H}-6^{\prime}$, dansyl), 2.67 (m, $\left.1 \mathrm{H}, \mathrm{H}-1^{\prime} \mathrm{a}\right), 2.49-2.41$ (m, $\left.2 \mathrm{H}, \mathrm{H}-5, \mathrm{H}-\mathrm{1}^{\prime} \mathrm{b}\right), 1.42-1.06$ (m, 8 H, H-2' $\left., \mathrm{H}-3^{\prime}, \mathrm{H}-4^{\prime}, \mathrm{H}-5^{\prime}\right) .{ }^{13} \mathrm{C} \mathrm{NMR}\left(75.5 \mathrm{MHz}, \mathrm{CD}_{3} \mathrm{OD}\right): \delta=105.6$ (J2,F $185.1 \mathrm{~Hz}, \mathrm{C}-2), 78.5\left(J_{3, \mathrm{~F}} 23.1 \mathrm{~Hz}, \mathrm{C}-3\right), 73.6\left(J_{4, \mathrm{~F}} 8.3 \mathrm{~Hz}, \mathrm{C}-4\right), 63.2\left(J_{1, \mathrm{~F}} 22.4 \mathrm{~Hz}, \mathrm{C}-1\right), 58.7(\mathrm{C}-6)$, $48.6\left(\mathrm{C}-1^{\prime}\right), 45.9,\left(J_{5, \mathrm{~F}} 4.1 \mathrm{~Hz}, \mathrm{C}-5\right), 45.8$ (dansyl), $43.7\left(\mathrm{C}-6^{\prime}\right), 30.4,30.3,27.7,27.3$ (C-2' $\left., \mathrm{C}-3^{\prime}, \mathrm{C}-4^{\prime}, \mathrm{C}-5^{\prime}\right)$. ${ }^{19} \mathrm{~F}$ NMR (470.3 MHz, CD $\left.{ }_{3} \mathrm{OD}\right): \delta=-184.4$. MS (MALDI): Calcd for $\left[\mathrm{C}_{6} \mathrm{H}_{12} \mathrm{FNO}_{3} \mathrm{H}\right]: \mathrm{m} / z 498.2438$ $[\mathrm{M}+\mathrm{H}]^{+}$; Found $[\mathrm{M}+\mathrm{H}]^{+} 498.2439$.

\subsection{Kinetic Studies}

Kinetic studies were performed at $37^{\circ} \mathrm{C}$ in an appropriate buffer (specific conditions depicted below). In a typical assay, the enzyme was incubated with different inhibitor concentrations for up to $5 \mathrm{~min}$ before initiating the reaction by the addition of substrate. The initial reaction rate was measured by monitoring the increase in absorbance at $400 \mathrm{~nm}$ for up to ten minutes using a Cary 4000 (Varian, Palo Alto, CA, USA). $K_{\mathrm{i}}$ determinations were performed using at least two different substrate concentrations. For each inhibitor, a range of four to six inhibitor concentrations bracketing the ultimately determined $K_{\mathrm{i}}$ value was used for each substrate concentration. Dixon plots ( $1 / \mathrm{v}$ vs. [I]) were constructed to validate the use of competitive inhibition model. The data were then fit using non-linear regression analysis with Grafit 7.0 [Erithacus Software, UK].

n.i. stands for no inhibition or weak inhibition with an estimated $K_{\mathrm{i}}$ value higher than $1 \mathrm{mM}$.

Specific Assay Conditions for Each Enzyme

Agrobacterium sp. $\beta$-glucosidase: $[69,70] 50 \mathrm{mM}$ sodium phosphate buffer (pH 7). Substrate: $p \mathrm{NP} \beta$-Gal, $K_{\mathrm{m}}=4.1 \mathrm{mM}$.

E. coli lac $z \beta$-galactosidase: $50 \mathrm{mM}$ sodium phosphate, $1.0 \mathrm{mM} \mathrm{MgCl} 2(\mathrm{pH} 7)$. Substrate: $p \mathrm{NP} \beta-\mathrm{Gal}, K_{\mathrm{m}}=60 \mu \mathrm{M}$. 
Bovine liver $\beta$-galactosidase: $50 \mathrm{mM}$ sodium phosphate buffer ( $\mathrm{pH}$ 7). Substrate: $p \mathrm{NP} \beta-\mathrm{Gal}$, $K_{\mathrm{m}}=0.65 \mathrm{mM}$.

Fabrazyme (Acid $\alpha$-galactosidase): $20 \mathrm{mM}$ sodium citrate, $50 \mathrm{mM}$ sodium phosphate, $1.0 \mathrm{mM}$ tetrasodium EDTA, $0.25 \% v / v$ Triton $\mathrm{X}-100^{\circledR}$ and $0.25 \% w / v$ taurocholic acid buffer (pH 5.5). Substrate: 2,4-DNP $\alpha$-Gal [71], $K_{\mathrm{m}}=0.65 \mathrm{mM}$.

GCase ( $\beta$-glucocerebrosidase): $20 \mathrm{mM}$ sodium citrate, $50 \mathrm{mM}$ sodium phosphate, $1.0 \mathrm{mM}$ tetrasodium EDTA, $0.25 \% v / v$ Triton $\mathrm{X}-100^{\circledR}$ and $0.25 \% w / v$ taurocholic acid buffer (pH 7). Substrate: 2,4-DNP $\beta$-Glc [71], $K_{\mathrm{m}}=2.7 \mathrm{mM}$.

S. cerevisiae $\alpha$-Glucosidase: $50 \mathrm{mM}$ sodium phosphate buffer (pH 7.0). Substrate: $p \mathrm{NP} \alpha$-Glc, $K_{\mathrm{m}}=0.75 \mathrm{mM}$.

Human $\beta$-galactosidase and $\beta$-hexosaminidase activity measurements were performed in duplicate assays, unless otherwise stated. Fibroblast cells were harvested by trypsinization in $0.9 \% \mathrm{NaCl}$ containing $0.01 \%$ Triton, homogenized by sonication $(3 \times 10 \mathrm{~s}$, Sonifier Bandelin Sonopuls, Bandelin, Berlin, Germany) and centrifuged at 13,000 rpm for $2 \mathrm{~min}$ in a table top centrifuge (Biofuge Pico, Heraeus, Hanau, Germany). Protein amounts were determined according to the method of Lowry [72].

For assessment of $\beta$-Gal activity, $20 \mu \mathrm{L}$ of cell homogenate were mixed with $100 \mu \mathrm{L}$ of $0.5 \mathrm{mM}$ 4-methylumbelliferyl- $\beta$-D-galactopyranoside (Sigma-Aldrich, St. Louis, MO, USA), in $100 \mathrm{mM}$ citrate buffer ( $\mathrm{pH} 4.0$ ) containing $100 \mathrm{mM} \mathrm{NaCl}$ and $0.02 \% \mathrm{NaN}_{3}$. After incubation at $37^{\circ} \mathrm{C}$ for $30 \mathrm{~min}$, the reaction was stopped by adding $2.5 \mathrm{~mL} 400 \mathrm{mM}$ glycine/ $\mathrm{NaOH}$ (pH 10.4).

$\beta$-Hexosaminidase activity was measured by adding $10 \mu \mathrm{L}$ homogenate to $90 \mu \mathrm{L} 0.9 \% \mathrm{NaCl}$ and $100 \mu \mathrm{L}$ of $1 \mathrm{mM} 4$-methylumbelliferyl- $N$-acetyl- $\beta$-D-glucosaminide (Sigma-Aldrich, St. Louis, MO, USA) in $100 \mathrm{mM}$ citrate buffer ( $\mathrm{pH} 4.6$ ) containing $0.2 \% \mathrm{BSA}$ and $0.04 \% \mathrm{NaN}_{3}$. The reaction was stopped after $10 \mathrm{~min}$ at $37^{\circ} \mathrm{C}$ by addition of $2.5 \mathrm{~mL}$ of $400 \mathrm{mM}$ glycine/ $\mathrm{NaOH}$ (pH 10.4). The amount of hydrolyzed 4-methylumbelliferone was determined with a fluorescence spectrometer Hitachi F7000 (Chiyoda, Japan). All compounds probed were found practically devoid of $\beta$-hexosaminidase inhibitory activity.

Modified $\beta$-Gal assays were used to estimate the half maximal inhibitory concentration $\left(\mathrm{IC}_{50}\right)$ of the particular chaperone. For $\mathrm{IC}_{50}$ determination, 0.001 to $100 \mu \mathrm{M}$ of chaperone was added to the assay mixture. Activity was measured in normal fibroblasts. Data analysis was performed with Microcal ${ }^{\mathrm{TM}}$ Origin ${ }^{\circledR}$ v6.0 (Origin Lab, Northampton, MA, USA) using a non-linear curve fitting module based on sigmoid curve fitting.

\subsection{CjGH35 Purification and Crystallisation}

CjGH35 was expressed and purified as in Larsbrink [73]. Crystals were grown by Sitting Drop Vapour Diffusion using protein at $25-36 \mathrm{mg} / \mathrm{mL}$ in $25 \mathrm{mM}$ HEPES pH 7.0, $100 \mathrm{mM} \mathrm{NaCl}$, in ratios of 0.8-1.2 $\mu \mathrm{L}$ to $1 \mu \mathrm{L}$ well solution, with the latter comprised of 2.3-2.8 M sodium acetate $\mathrm{pH}$ 7.4-7.6. Crystals were soaked with a speck of solid ligand powder, introduced into the drop on the end of a needle, for 1 to 3 days, and frozen directly into liquid nitrogen using Hampton CryoLoops ${ }^{\mathrm{TM}}$ (Hampton, CA, USA).

\subsection{Data Collection and Structure Refinement}

Data were collected at the Diamond Light Source on beamlines IO4 (1, 16 and 17), IO4-1 (31) and IO2 (14 and 22), and processed using DIALS (1, 16, 17, 22 and 31) [74] or XDS (14) [75]. All data were scaled with AIMLESS [76] to resolutions of 1.46 to $1.60 \AA$, and were in space group P1. The structures were solved by molecular replacement using REFMAC (for 1, 16, 17 and 22) [77] or PHASER (31 and 14) [78] using the structure of $4 \mathrm{D} 1 \mathrm{I} . \mathrm{pdb}$ without water molecules and ions as the model. The datasets were in space group P1, with 8 molecules in the asymmetric unit. The structures were refined using REFMAC, with twin refinement using observed intensities converted to amplitudes employed in the case of 14, and anisotropic $B$-factor refinement employed for all of the structures. Manual rebuilding was performed using Coot [79] followed by cycles of refinement, and the ligand molecules were added 
into $2 m F_{o}-D F_{c}$ density maps calculated after the protein chains had been modelled and most of the water molecules and sodium ions added. The crystallographic programs were run within the CCP4I2 suite [80].

\subsection{Patients and Cell Lines}

Cell lines from one $\mathrm{G}_{\mathrm{M} 1}$-Gangliosidosis-patient (R201C) and one WT, were exposed to compounds 22, 31, and 37, for evaluation of their chaperone effects.

Human skin fibroblasts were grown in minimal essential medium (MEM) with Earle's Salts (Sigma Aldrich, St. Louis, MO, USA) containing 10\% fetal bovine serum, $400 \mu \mathrm{M}$ L-glutamine, and $50 \mu \mathrm{g} / \mathrm{mL}$ gentamycin at $37^{\circ} \mathrm{C}$ and $5 \% \mathrm{CO}_{2}$. All cells used in this study were between the third and nineteenth passages.

Potential chaperones were dissolved in DMSO and diluted in $10 \mathrm{mM}$ phosphate buffer (pH 7.0) containing $100 \mathrm{mM} \mathrm{NaCl}, 0.01 \% \mathrm{NaN}_{3}$, and $0.01 \%$ Triton for the $\mathrm{IC}_{50}$-measurements and in $\mathrm{MEM}$ for the in-vivo tests. The total DMSO concentration in the media was less than $1 \%$ and had no effect on $\beta-G a l$ activity or cell viability.

\subsection{Treatment of Cultured Fibroblasts}

Fibroblasts were grown to semi-confluency in 6-well plates. Particular chaperone was added to the culture medium at following concentrations: 100-0.02 $\mu \mathrm{mol}$. Cells were incubated for four additional days at $37^{\circ} \mathrm{C}$. Cells were harvested by scraping and prepared for $\beta$-galactosidase and $\beta$-hexosaminidase assays as described above.

Supplementary Materials: The following are available online at. XRD data and NMR spectra for new compounds.

Author Contributions: P.W., S.A. and M.S. performed the syntheses for cyclopentanes; M.T. (Martin Thonhofer). performed the syntheses for isofagomines; A.W. assisted with the development and the syntheses; A.T. and P.M. provided crystal structure for compound 34; W.A.O. and G.J.D. provided enzyme-inhibitor crystal structures; S.A.N., B.M.P., C.T., A.G.S. and M.T. (Marion Tschernutter). performed biochemical and medicinal experiments; A.E.S. and T.M.W. conceived and designed the synthetic experiments; E.P., W.W. as well as S.G.W. supervised and evaluated biochemical and medicinal studies; A.E.S. planned the study. All authors have read and agreed to the published version of the manuscript.

Funding: Financial support by the Austrian Fonds zur Förderung der Wissenschaftlichen Forschung (FWF), Vienna, (Project P 24815-B21) is gratefully acknowledged. S.G.W. thanks GlycoNet, the Canadian Network of Centres of Excellence in glycoscience, for financial support. P.W. is recipient of a DOC Fellowship of the Austrian Academy of Sciences at the Institute of Chemistry and Technology of Biobased Systems, Graz University of Technology.

Acknowledgments: Open access funding by Graz University of Technology is appreciated.

Conflicts of Interest: The authors declare no conflict of interest.

\section{References}

1. Compain, P.; Martin, O.R. (Eds.) Iminosugars_From Synthesis to Therapeutic Applications; Wiley: Hoboken, NJ, USA, 2007.

2. Wennekes, T.; van den Berg, R.J.B.H.N.; Boot, R.G.; van der Marel, G.A.; Overkleeft, H.S.; Aerts, J.M.F.G. Glycosphingolipids-Nature, Function, and Pharmacological Modulation. Angew. Chem. Int. Ed. 2009, 48, 8848-8869. [CrossRef]

3. Sun, A. Lysosomal storage disease overview. Ann. Transl. Med. 2018, 6, 476. [CrossRef] [PubMed]

4. Lachmann, R.H. Enzyme replacement therapy for lysosomal storage diseases. Pediatrics 2011, 6, 588-593. [CrossRef] [PubMed]

5. Condori, J.; Acosta, W.; Ayala, J.; Katta, V.; Flory, A.; Martin, R.; Radin, J.; Cramer, C.J.; Radin, D.N. Enzyme replacement for GM1-gangliosidosis: Uptake, lysosomal activation, and cellular disease correction using a novel $\beta$-galactosidase: RTB lectin fusion. Mol. Genet. Metab. 2016, 117, 199-209. [CrossRef] [PubMed]

6. Lund, T.C. Hematopoietic stem cell transplantation for lysosomal storage diseases. Pediatr. Endocrinol. Rev. 2013, 11, 91-98. [CrossRef] 
7. Biffi, A. Hematopoietic Stem Cell Gene Therapy for Storage Disease: Current and New Indications. Cell Press 2017, 25, 1155-1162. [CrossRef]

8. Biffi, A. Gene therapy for lysosomal storage disorders: A good start. Hum. Mol. Genet. 2016, 25, R65-R75. [CrossRef]

9. Yew, N.S.; Cheng, S.H. Gene therapy for lysosomal storage disorders. Pediatr. Endocrinol. Rev. 2013, 11, 99-109. [CrossRef]

10. Macauley, S.L. Combination Therapies for Lysosomal Storage Diseases: A Complex Answer to a Simple Problem. Pediatr. Endocrinol. Rev. 2016, 13, 639-648.

11. Platt, F.M.; Jeyakumar, M.; Andersson, U.; Priestman, D.A.; Dwek, R.A.; Butters, T.D.; Cox, T.M.; Lachmann, R.; Hollak, C.; Aerts, J.M.F.G.; et al. Inhibition of Substrate Synthesis as a Strategy for Glycolipid Storage Disease Therapy. J. Inherit. Metab. Dis. 2001, 24, 275-290. [CrossRef]

12. Lachmann, R.H.; Platt, F.M. Substrate Reduction Therapy for Glycosphingolipid Storage Disorders. Expert Opin. Investig. Drugs 2001, 10, 455-466. [CrossRef] [PubMed]

13. Coutinho, M.F.; Santos, J.I.; Matos, L.; Alves, S. Genetic Substrate Reduction Therapy: A Promising Approach for Lysosomal Storage Disorders. Diseases 2016, 4, 33. [CrossRef] [PubMed]

14. Fan, J.-Q.; Ishii, S.; Asano, N.; Suzuki, Y. Accelerated transport and maturation of lysosomal $\alpha$-galactosidase A in Fabry lymphoblasts by an enzyme inhibitor. Nat. Med. 1999, 5, 112-115. [CrossRef] [PubMed]

15. Morello, J.-P.; Petäjä-Repo, U.E.; Bichet, D.G.; Bouvier, M. Pharmacological chaperones: A new twist on receptor folding. Trends Pharm. Sci. 2000, 21, 466-469. [CrossRef]

16. Suzuki, Y.; Ogawa, S.; Sakakibara, Y. Chaperone Therapy for Neuronopathic Lysosomal Diseases: Competitive Inhibitors as Chemical Chaperones for Enhancement of Mutant Enzyme Activities. Persp. Med. Chem. 2009, 3, 7-19. [CrossRef]

17. Parenti, G.; Pignata, C.; Vajro, P.; Salerno, M. New strategies for the treatment of lysosomal storage diseases. Int. J. Mol. Med. 2013, 31, 11-20. [CrossRef]

18. Suzuki, Y. Emerging novel concept of chaperone therapies for protein misfolding diseases. Proc. Jap. Acad. Ser. B Phys. Biol. Sci. 2014, 90, 145-162. [CrossRef]

19. Parenti, G.; Moracci, M.; Fecarotta, S.; Andria, G. Pharmacological chaperone therapy for lysosomal storage diseases. Future Med. Chem. 2014, 6, 1031-1045. [CrossRef]

20. Small, S.A. Pharmacological chaperones in the age of proteomic pathology. Proc. Natl. Acad. Sci. USA 2014, 111, 12274-12275. [CrossRef]

21. Covertino, M.; Das, J.; Dokholyan, N.V. Pharmacological Chaperones: Design and Development of New Therapeutic Strategies for the Treatment of Conformational Diseases. Chem. Biol. 2016, 11, 1471-1489. [CrossRef]

22. Sanchez-Fernandez, E.M.; Garcia Fernandez, J.M.; Ortiz Mellet, C. Glycomimetic-based pharmacological chaperones for lysosomal storage disorders: Lessons from Gaucher, GM1-gangliosidosis and Fabry diseases. Chem. Commun. 2016, 5497-5515. [CrossRef] [PubMed]

23. Boyd, R.E.; Lee, G.; Rybczynski, P.; Benjamin, E.R.; Khanna, R.; Wustman, B.A.; Valenzano, K.J. Pharmacological Chaperones as Therapeutics for Lysosomal Storage Diseases. J. Med. Chem. 2013, 56, 2705-2725. [CrossRef] [PubMed]

24. Wrodnigg, T.M.; Stütz, A.E. The Two Faces of Iminoalditols: Powerful Inhibitors Trigger Glycosidase Activation. Curr. Enzym. Inhib. 2012, 8, 47-99. [CrossRef]

25. Shin, M.H.; Lim, H.-S. Screening methods for identifying pharmacological chaperones. Mol. Biosyst. 2017, 13, 638-647. [CrossRef]

26. Arenz, C. Recent advances and novel treatments for sphingolipidoses. Future Med. Chem. 2017, 9, 1685-1698. [CrossRef]

27. Benito, J.M.; García Fernández, J.M.; Ortiz Mellet, C. Pharmacological chaperone therapy for Gaucher disease: A patent review. Expert Opin. Pat. 2011, 21, 885-903. [CrossRef]

28. Sawkar, A.R.; Adamski-Werner, S.L.; Cheng, W.-C.; Wong, C.-H.; Beutler, E.; Zimmer, K.-P.; Kelly, J.W. Gaucher Disease-Associated Glucocerebrosidases Show Mutation-Dependent Chemical Chaperoning Profiles. Chem. Biol. 2005, 12, 1235-1244. [CrossRef]

29. Wennekes, T.; van den Berg, R.J.B.H.N.; Donker, W.; van der Marel, G.A.; Strijland, A.; Aerts, M.F.G.; Overkleeft, H.S. Development of Adamantan-1-yl-methoxy-Functionalized 1-Deoxynojirimycin Derivatives as Selective Inhibitors of Glucosylceramide Metabolism in Man. J. Org. Chem. 2007, 72, 1088-1097. [CrossRef] 
30. Alfonso, P.; Andreu, V.; Pino-Angeles, A.; Moya-Garcia, A.A.; Garcia-Moreno, M.I.; Rodriguez-Rey, J.C.; Sanchez-Jimenez, F.; Pocovi, M.; Ortiz Mellet, C.; Garcia Fernandez, J.M.; et al. Bicyclic Derivatives of L-Idonojirimycin as Pharmacological Chaperones for Neuronopathic Forms of Gaucher Disease. ChemBioChem 2013, 14, 943-949. [CrossRef]

31. Li, Z.; Li, T.; Dai, S.; Xie, X.; Ma, X.; Zhao, W.; Zhang, W.; Li, J.; Wang, P.G. New Insights into the Pharmacological Chaperone Activity of C2-Substituted Glucoimidazoles for the Treatment of Gaucher Disease. ChemBioChem 2013, 14, 1239-1247. [CrossRef]

32. Suzuki, Y.; Oshima, A.; Nanba, E. The Metabolic and Molecular Bases of Inherited Disease; Shriver, C.R., Beaudet, A.L., Sly, W.S., Valle, D., Eds.; McGraw-Hill: New York, NY, USA, 2001; pp. 3775-3809.

33. Brunetti-Pierri, N.; Scaglia, F. $\mathrm{G}_{\mathrm{M} 1}$ Gangliosidosis: Review of clinical, molecular, and therapeutic aspects. Mol. Genet. Metabol. 2008, 94, 391-396. [CrossRef] [PubMed]

34. Matsuda, J.; Suzuki, O.; Oshima, A.; Yamamoto, Y.; Noguchi, A.; Takimoto, K.; Itoh, M.; Matsuzaki, Y.;

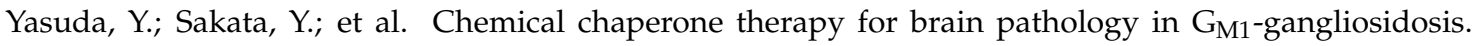
Proc. Natl. Acad. Sci. USA 2003, 100, 15912-15917. [CrossRef] [PubMed]

35. Higaki, K.; Li, L.; Okuzawa, S.; Takamuram, A.; Yamamoto, K.; Adachi, K.; Paraguison, R.C.; Takai, T.; Ikehata, H.; Tominaga, L.; et al. Chemical Chaperone Therapy: Chaperone Effect on Mutant Enzyme and Cellular Pathophysiology in $\beta$-Galactosidase Deficiency. Hum. Mutat. 2011, 32, 843-852. [CrossRef] [PubMed]

36. Kuno, S.; Higaki, K.; Takahashi, A.; Nanba, E.; Ogawa, S. Potent chemical chaperone compounds for

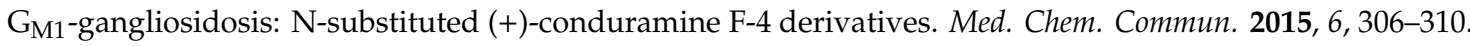
[CrossRef]

37. Takai, T.; Higaki, K.; Aguilar-Moncayo, M.; Mena-Barragan, T.; Hirano, Y.; Yura, K.; Yu, L.; Ninomiya, H.; Garcia-Moreno, M.I.; Sakakibara, Y.; et al. A Bicyclic 1-Deoxygalactonojirimycin Derivative as a Novel Pharmacological Chaperone for $\mathrm{G}_{\mathrm{M} 1}$ Gangliosidosis. Mol. Ther. 2013, 21, 526-532. [CrossRef]

38. Siriwardena, A.; Sonawane, D.P.; Bande, O.P.; Markad, P.R.; Yonekawa, S.; Tropak, M.B.; Ghosh, S.; Chopade, B.A.; Mahuran, D.J.; Dhavale, D.D. Synthesis of 1,5-Dideoxy-1,5-iminoribitol C-Glycosides through a Nitrone-Olefin Cycloaddition Domino Strategy: Identification of Pharmacological Chaperones of Mutant Human Lysosomal $\beta$-Galactosidase. J. Org. Chem. 2014, 79, 4398-4404. [CrossRef]

39. Kasperzyk, J.L.; El-Abbadi, M.M.; Hauser, E.C.; d'Azzo, A.; Platt, F.M.; Seyfried, T.N. N-butyldeoxygalactonojirimycin reduces neonatal brain ganglioside content in a mouse model of $\mathrm{G}_{\mathrm{M} 1}$ gangliosidosis. J. Neurochem. 2004, 89, 645-653. [CrossRef]

40. Rigat, B.A.; Tropak, M.B.; Buttner, J.; Crushell, E.; Benedict, D.; Callahan, J.W.; Martin, D.R.; Mahuran, D.J. Evaluation of $N$-nonyl-deoxygalactonojirimycin as a pharmacological chaperone for human $\mathrm{G}_{\mathrm{M} 1}$ gangliosidosis leads to identification of a feline model suitable for testing enzyme enhancement therapy. Mol. Genet. Metab. 2012, 107, 203-212. [CrossRef]

41. Fantur, K.; Hofer, D.; Schitter, G.; Steiner, A.J.; Pabst, B.M.; Wrodnigg, T.M.; Stütz, A.E.; Paschke, E. DLHex-DGJ, a novel derivative of 1-deoxygalactonojirimycin with pharmacological chaperone activity in

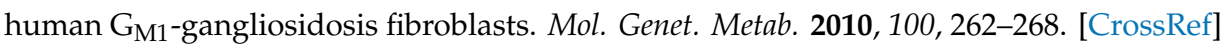

42. Schitter, G.; Steiner, A.J.; Pototschnig, G.; Scheucher, E.; Thonhofer, M.; Tarling, C.A.; Withers, S.G.; Fantur, K.; Paschke, E.; Mahuran, D.J.; et al. Fluorous Iminoalditols: A New Family of Glycosidase Inhibitors and Pharmacological Chaperones. ChemBioChem 2010, 11, 2026-2033. [CrossRef]

43. Suzuki, H.; Otho, U.; Higaki, K.; Mena-Barragan, T.; Aguilar-Moncayo, M.; Ortiz Mellet, C.; Nanba, E.; Garcia Fernandez, J.M.; Suzuki, Y.; Shimizu, T. Structural Basis of Pharmacological Chaperoning for Human $\beta$-Galactosidase. J. Biol. Chem. 2014, 289, 14560-14568. [CrossRef]

44. Front, S.; Gallienne, E.; Charollais-Thoenig, J.; Demotz, S.; Martin, O. N-Alkyl-, 1-C-Alkyl-, and 5-C-Alkyl-1,5-dideoxy-1,5-imino-L-ribitols as Galactosidase Inhibitors. ChemMedChem 2016, 11, 133-141. [CrossRef] [PubMed]

45. Ichikawa, Y.; Igarashi, Y.; Ichikawa, M.; Suhara, Y. 1-N-Iminosugars: Potent and Selective Inhibitors of $\beta$-Glycosidases. J. Am. Chem. Soc. 1998, 120, 3007-3018. [CrossRef]

46. Thonhofer, M.; Hojnik, C.; Schalli, M.; Zoidl, M.; Wrodnigg, T.M.; Stütz, A.E.; Withers, S.G. New 4-epi-Isofagomine Derivatives for Glycosidase Research. In Proceedings of the 97th Canadian Chemisty Conference and Exhibition, Vancouver, BC, Canada, 1-6 June 2014. 
47. Thonhofer, M.; Weber, P.; Gonzalez Santana, A.; Christina, T.; Roland, F.; Bettina, M.P.; Eduard, P.; Michael, S.; Arnold, E.S.; Marion, T.; et al. Synthesis of C-5a-substituted derivatives of 4-epi-isofagomine: Notable $\beta$-galactosidase inhibitors and activity promotors of $\mathrm{G}_{\mathrm{M} 1}$-gangliosidosis related human lysosomal $\beta$-galactosidase mutant R201C. Carbohydr. Res. 2016, 429, 71-80. [CrossRef] [PubMed]

48. Martin, O.R.; Gallienne, E.; Front, S.; Charollais, J.; Demotz, S. 4-epi-Isofagomine derivatives, Eur. Pat. Appl. 2015, 2015, 90-92.

49. Front, S.; Biela-Banas, A.; Burda, P.; Ballhausen, D.; Higaki, K.; Caciotti, A.; Morrone, A.; Charollais-Thoenig, J.; Gallienne, E.; Demotz, S.; et al. (5aR)-5a-C-Pentyl-4-epi-isofagomine: A powerful inhibitor of lysosomal $\beta$-galactosidase and a remarkable chaperone for mutations associated with GM1-gangliosidosis and Morquio disease type B. Eur. J. Med. Chem. 2017, 126, 160-170. [CrossRef] [PubMed]

50. Front, S.; Almeida, S.; Zoete, V.; Charollais-Thoenig, J.; Gallienne, E.; Marmy, C.; Pilloud, V.; Marti, R.; Wood, T.; Martin, O.R.; et al. 4-epi-Isofagomine derivatives as pharmacological chaperones for the treatment of lysosomal diseases linked to $\beta$-galactosidase mutations: Improved synthesis and biological investigations. Bioorg. Med. Chem. 2018, 26, 5462-5469. [CrossRef]

51. Schalli, M.; Tysoe, C.; Fischer, R.; Pabst, B.M.; Thonhofer, M.; Paschke, E.; Rappitsch, T.; Stütz, A.E.; Tschernutter, M.; Windischhofer, W.; et al. N-Substituted 5-amino-1-hydroxymethyl-cyclopentanetriols: A new family of activity promotors for a $\mathrm{G}_{\mathrm{M} 1}$-gangliosidosis related human lysosomal $\beta$-galactosidase mutant. Carbohydr. Res. 2017, 443-444, 15-22. [CrossRef]

52. Leroy, E.; Reymond, J.L. Anomer-Selective Inhibition of Glycosidases Using Aminocyclopentanols. Org. Lett. 1999, 1, 775-777. [CrossRef]

53. Greul, J.N.; Kleban, M.; Schneider, B.; Picasso, S.; Jäger, V. Amino(hydroxymethyl)cyclopentanetriols, an Emerging Class of Potent Glycosidase Inhibitors Part II: Synthesis, Evaluation, and Optimization of ß-D-Galactopyranoside Analogues. ChemBioChem 2001, 2, 368-370. [CrossRef]

54. Gartenmann Dickson, L.; Leroy, E.; Reymond, J.-L. Structure-activity relationships in aminocyclopentitol glycosidase inhibitors. Org. Biomol. Chem. 2004, 2, 1217-1226. [CrossRef] [PubMed]

55. Schalli, M.; Weber, P.; Tysoe, C.; Pabst, B.M.; Thonhofer, M.; Paschke, E.; Stütz, A.E.; Tschernutter, M.; Windischhofer, W.; Withers, S.G. A new type of pharmacological chaperone for $\mathrm{G}_{\mathrm{M} 1}$-gangliosidosis related human lysosomal $\beta$-galactosidase: N-Substituted 5-amino-1-hydroxymethyl-cyclopentanetriols. Bioorg. Med. Chem. Lett. 2017, 27, 3431-3435. [CrossRef] [PubMed]

56. Thonhofer, M.; Weber, P.; Gonzalez Santana, A.; Fischer, R.; Pabst, B.M.; Paschke, E.; Schalli, M.; Stütz, A.E.; Tschernutter, M.; Windischhofer, W.; et al. Synthesis of C-5a-chain extended derivatives of 4-epi-isofagomine: Powerful $\beta$-galactosidase inhibitors and low concentration activators of $\mathrm{G}_{\mathrm{M} 1}$-gangliosidosis-related human lysosomal $\beta$-galactosidase. Bioorg. Med. Chem. Lett. 2016, 26, 1438-1442. [CrossRef]

57. Weber, P.; Nasseri, S.A.; Pabst, B.M.; Torvisco, A.; Müller, P.; Paschke, E.; Tschernutter, M.; Windischhofer, W.; Withers, S.G.; Wrodnigg, T.M.; et al. Potent GH20 N-Acetyl- $\beta$-D-hexosaminidase Inhibitors: N-Substituted 3-acetamido-4-amino-5-hydroxymethyl-cyclopentanediols. Molecules 2018, 23, 708. [CrossRef] [PubMed]

58. Lombard, V.; Golaconda Ramulu, H.; Drula, E.; Coutinho, P.M.; Henrissat, B. The Carbohydrate-active enzymes database in 2013. Nucleic Acids Res. 2014, 42, D490-D495. [CrossRef]

59. CAZypedia Consortium. Ten years of CAZypedia: A living encyclopedia of carbohydrate-active enzymes. Glycobiology 2018, 28, 3-8. [CrossRef]

60. McNicholas, S.; Potterton, E.; Wilson, K.S.; Noble, M.E.M. Presenting your structures: The CCP4mg molecular-graphics software. Acta Cryst. 2011, D67, 386-394. [CrossRef]

61. Hermetter, A.; Scholze, H.; Stütz, A.E.; Withers, S.G.; Wrodnigg, T.M. Powerful probes for glycosidases: Novel fluorescently tagged glycosidase inhibitors. Bioorg. Med. Chem. Lett. 2001, 11, 1339-1342. [CrossRef]

62. Wrodnigg, T.M.; Diness, F.; Gruber, C.; Häusler, H.; Lundt, I.; Rupitz, K.; Steiner, A.J.; Stütz, A.E.; Tarling, C.A.; Withers, S.G.; et al. Probing the aglycon binding site of a $\beta$-glucosidase: A collection of C-1-modified 2,5-dideoxy-2,5-imino-D-mannitol derivatives and their structure-activity relationships as competitive inhibitors. Bioorg. Med. Chem. 2004, 12, 3485-3495. [CrossRef]

63. Greimel, P.; Häusler, H.; Lundt, I.; Rupitz, K.; Stütz, A.E.; Tarling, C.A.; Withers, S.G.; Wrodnigg, T.M. Fluorescent glycosidase inhibiting 1,4-dideoxy-1,5-iminoalditols. Bioorg. Med. Chem. Lett. 2006, 16, 2067-2070. [CrossRef] 
64. Aguilar-Moncayo, M.; Garcia-Moreno, M.I.; Stütz, A.E.; Garcia Fernandez, J.M.; Wrodnigg, T.M.; Ortiz Mellet, C. Fluorescent-tagged $\mathrm{sp}^{2}$-iminosugars with potent $\beta$-glucosidase inhibitory activity. Bioorg. Med. Chem. 2010, 18, 7439-7445. [CrossRef] [PubMed]

65. Sheldrick, G.M. SHELXT-Integrated space-group and crystal-structure determination. Acta Cryst. 2015, A71, 3-8. [CrossRef] [PubMed]

66. Spek, A.L. Single-crystal structure validation with the program PLATON. J. Appl. Cryst. 2003, 36, 7-13. [CrossRef]

67. Spek, A.L. Structure validation in chemical crystallography. Acta Cryst. Sect. D 2009, 65, 148-155. [CrossRef]

68. Krivickas, S.J.; Tamanini, E.; Todd, M.H.; Watkinson, M. Effective Methods for the Biotinylation of Azamacrocycles. J. Org. Chem. 2007, 72, 8280-8289. [CrossRef]

69. Prade, H.; Mackenzie, L.F.; Withers, S.G. Enzymatic synthesis of disaccharides using Agrobacterium sp. $\beta$-glucosidase. Carbohydr. Res. 1998, 305, 371-381. [CrossRef]

70. Kempton, J.B.; Withers, S.G. Mechanism of Agrobacterium $\beta$-Glucosidase: Kinetic Studies. Biochemistry 1992, 31, 9961-9969. [CrossRef]

71. Chen, H.-M.; Withers, S.G. Facile Synthesis of 2,4-Dinitrophenyl $\alpha$-D-Glycopyranosides as Chromogenic Substrates for $\alpha$-Glycosidases. ChemBioChem 2007, 8, 719-722. [CrossRef] [PubMed]

72. Lowry, O.H.; Rosebrough, N.J.; Farr, A.L.; Randall, R.J. Protein Measurement with the Folin Phenol Reagent. J. Biol. Chem. 1951, 193, 265-275.

73. Larsbrink, J.; Thompson, A.J.; Lundqvist, M.; Gardner, J.G.; Davies, G.J.; Brumer, H. A complex gene locus enables xyloglucan utilization in the model saprophyte Cellvibrio japonicus. Mol. Microbiol. 2014, 94, 418-433. [CrossRef]

74. Winter, G.; Waterman, D.G.; Parkhurst, J.M.; Brewster, A.S.; Gildea, R.J.; Gerstel, M.; Fuentes-Montero, L.; Vollmar, M.; Michels-Clark, T.; Young, I.D.; et al. DIALS: Implementation and evaluation of a new integration package. Acta Cryst. Sect. D 2018, 74, 85-97. [CrossRef] [PubMed]

75. Kabsch, W. XDS. Acta Cryst. Sect. D 2010, 66, 125-132. [CrossRef] [PubMed]

76. Evans, P.R.; Murshudov, G.N. How good are my data and what is the resolution? Acta Cryst. Sect. D 2013, 69, 1204-1214. [CrossRef] [PubMed]

77. Murshudov, G.N.; Skubak, P.; Lebedev, A.A.; Pannu, N.S.; Steiner, R.A.; Nicholls, R.A.; Winn, M.D.; Long, F.; Vagin, A.A. REFMAC5 for the refinement of macromolecular crystal structures. Acta Cryst. Sect. D 2011, 67, 355-367. [CrossRef]

78. McCoy, A.J.; Grosse-Kunstleve, R.W.; Adams, P.D.; Winn, M.D.; Storoni, L.C.; Read, R.J. Phaser crystallographic software. J. Appl. Crystallogr. 2007, 40, 658-674. [CrossRef]

79. Emsley, P.; Lohkamp, B.; Scott, W.G.; Cowtan, K. Features and development of Coot. Acta Cryst. Sect. D 2010, 66, 486-501. [CrossRef]

80. Potterton, L.; Agirre, J.; Ballard, C.; Cowtan, K.; Dodson, E.; Evans, P.R.; Jenkins, H.T.; Keegan, R.; Krissinel, E.; Stevenson, K.; et al. CCP4i2: The new graphical user interface to theCCP4 program suite. Acta Cryst. Sect. D 2018, 74, 68-84. [CrossRef]

Sample Availability: Samples of the compound $\mathbf{1 7}$ are available from the authors.

(C) 2020 by the authors. Licensee MDPI, Basel, Switzerland. This article is an open access article distributed under the terms and conditions of the Creative Commons Attribution (CC BY) license (http://creativecommons.org/licenses/by/4.0/). 